\title{
Professional and personal ethics in translation: A survey of South African translators' strategies and motivations
}

\author{
Haidee Kruger and Elizabeth Crots \\ School of Languages, Vaal Triangle Campus, North-West University, South Africa \\ E-mail: haidee.kruger@nwu.ac.za
}

\begin{abstract}
The aim of the study reported on in this article was to explore South African translators' responses to various kinds of ethically contentious material at the textual level, in the context of particular text types and hypothetical translation situations. The study made use of a survey design based primarily on closed-ended questions, administered to an availability sample of 31 South African translators drawn from the membership of the South African Translators' Institute (SATI). The survey was, in the first instance, designed to solicit respondents' opinions regarding which translation strategies they would most likely select to deal with particular kinds of ethical challenges. In order to better understand the factors affecting the selection of translation strategies, the impact of two translator factors (experience and age) and two text factors (text type and type of ethical problem) was investigated. In the second instance, the survey aimed to investigate why respondents selected particular strategies, and indirectly how they view their ethical responsibility. To this end, possible reasons for the selection of specific translation strategies were formulated and categorised as primarily influenced by either personal or professional ethics. In addition to this overall analysis, the study analysed differences in the role of personal and professional ethics depending on the type of ethical problem, the type of text, respondents' age, and different levels of translation experience. The findings of the study suggest an overwhelming preference for faithful translation, but also reveal an interplay between personal and professional ethics as the motivation for this choice, with some differences across text type and kind of ethical problem. It appears that experience leads to a greater preference for both faithful translation strategies and a stronger influence of professional ethics. However, the data also suggest that age and/or generational differences may play a role in the selection of translation strategies, as well as in the effect of personal and professional ethics, with the oldest and youngest respondents in the sample more likely to opt for strategies other than faithful translation, motivated more frequently by personal rather than professional ethics.
\end{abstract}

Keywords: ethics, professional ethics, personal ethics, translation strategies, South Africa, Afrikaans, English, sexism, racism, crude language 


\section{Introduction}

The concept of 'ethics' is complex and multifaceted. It stands in an intricate relationship with morality (see Hinman 2013:4-5, Koskinen 2000:11), and may be conceptualised in various ways. It may broadly be conceived of in deontological or teleological terms (Baker 2011:276277), and within this basic tension, may be defined within an array of different frameworks, such as absolutism, relativism (Hinman 2013:24), consequentialism or utilitarianism (Hooker 2010:444, Singer 2011), and Kantianism (Hinman 2013:158). Ethics may also be viewed from within the paradigms of rights (Hinman 2013:211), character or virtue (Hinman 2013:248-277, Slote 2010:478), and diversity (Hinman 2013:325). ${ }^{1}$

These varied conceptions of ethics are also reflected in notions of translation ethics. In the everyday setting of most translators' work, the concept 'ethics' is usually invoked within the formal discursive framework of a code of practice, conduct or ethics (in French déontologie see Pym 2012:1). This is a narrower, codified, professional view of ethics, where the translator is seen as having responsibilities and rights vis-à-vis the immediate professional context within which the mediated text is created. In this view, the ethical relationships involved are primarily limited to those professional relationships between the translator, client and text. This is the view of ethics expressed in most codes of ethics of organisations representing translators' interests (see ATA 2010, AUSIT 2012, FIT 1994, SATI 2013), which tend to be concerned with matters limited to the immediate professional context of the translation, such as accuracy and quality, confidentiality, fairness in remuneration, professionalism in relationships with clients, and responsibility towards the profession itself.

Pym (2012:1) sets this limited professional view of ethics (déontologie) against the more philosophical view of ethics (éthique), which is concerned more with universal, abstract principles (e.g. 'justice' or 'fairness') as they apply to humanity in general. This latter perspective on ethics has also had a substantial influence on thinking about translational ethics. In this view, translational ethics has a much wider ambit, and the translator's ethical responsibilities and rights are seen as operating in a context far greater than the immediate professional environment within which a translation is produced, to include the entire sociocultural and -political context from which, in which, and for which translations are both produced and disseminated. This is the view elaborated by scholars such as Cronin (2003), who argues that the asymmetrical power relationships between cultures and languages "lead to an extended notion of what constitutes the translator's responsibility in the era of globalization" (Cronin 2003:134). Specifically, this raises the question whether the ethical responsibility of translators is to the profession itself, only, or whether there is also an ethical responsibility arising from "translation as a cultural fact" (Cronin 2003:134). For Cronin (2003:134), this means that there must, of necessity, be "an activist dimension to translation which involves an engagement with the cultural politics of society at national and international levels" (Cronin $2003: 134)$. It is this conception of the translator as a dynamic, active agent that has an ethical responsibility and rights in the shaping of social and cultural exchange in a globalised world fraught with inequality and conflict that underlies much recent thinking on translation ethics.

This broader view of the translator's ethical rights and responsibilities, however, is not generally emphasised in professional codes of conduct. Many practitioners (as well as scholars),

\footnotetext{
${ }^{1}$ See Skorupski (2010) for a comprehensive overview of these and other matters relating to ethics.
} 
believe, along with Chesterman (2001:147), that political activism and engagement do not form part of professional ethics, as such: "A translator may be actively engaged in support of a worthy cause, and may translate in such a way as to support this cause, but these are factors that are additional to professional ethics proper, not part of them".

Activism and engagement in translation - this wider socio-cultural and -political role of translators - may therefore be regarded as part of professional ethics, as Cronin (2003) views it, or more properly as part of the translator's personal ethics, as Chesterman (2001) sees it. This raises the third context from within which translation ethics may be conceptualised: the personal. Translators are humans, and like all humans, they have a system of beliefs that inform how they choose to live their lives. It should already be apparent from the above discussion that separating personal and professional ethics may be difficult, and, as Koskinen (2000:15) points out, "as our awareness of the various influences of translation has increased, it has become more and more evident that it is also relevant to contemplate how to resolve situations where professional ethics clash with the translators' personal moral convictions".

These three conceptualisations of ethics (which are also echoed in Inghilleri's (2009:100) formulation of "ethical responsibility, social activism and personal integrity" as the urgent issues that require attention in the field) may be seen as premised on three different relationships of responsibility or loyalty. The first, narrower conception of professional ethics is founded on responsibility towards the client, the text, and the profession (see also Pym 2012:76-81). The second, wider conception of ethics as involving a responsibility to resist situations of injustice or unfairness is founded on responsibility towards society at large, and general ethical principles of justice and equity. Lastly, personal ethics may be seen as founded on loyalty towards the translator's own system of beliefs. In practice, these three types of ethics, and their loyalties, may overlap - but they may also be in conflict. In any given scenario, complex relationships between different ethical injunctions may be at play in translators' decisions about whether to translate and how to translate.

Approaches to ethics may be either descriptive or prescriptive (Chesterman 1997:171; see also Inghilleri 2009), and may draw on both conceptual and empirical methods, or a combination of the two. An overview of existing research suggests that, often, the descriptive empirical data used in discussions of ethics are drawn from case studies of predominantly literary translation, as in Venuti (1998, 2008), or alternatively exemplary discussions or case studies of translation and interpreting in environments characterised by overt and/or violent conflict (see, for example, Baker 2006, Inghilleri and Harding 2010). While these data no doubt contribute to our understanding of the interaction between politics, ethics and agency in the work of translators, there is also clearly a need for more comprehensive descriptive data on all the assorted situations in between these foci, to explore how translators in a variety of contexts respond to miscellaneous ethical dilemmas in their daily work. Such descriptive data would contribute to a better understanding of a number of interrelated issues, such as translators':

- actual ethical decision-making, leading to the choice of particular strategies for the translation of contentious material;

- motivations for particular translation choices;

- awareness of codified ethical guidelines;

- perception of their own agency in intercultural exchange in a world characterised by imbalances in power, and 
- perception of the interaction between personal and professional ethics in their decision-making processes.

The aim of the study reported on in this article was to explore South African translators' responses to various kinds of ethically contentious material at the textual level, in the context of particular text types and hypothetical translation situations. The study made use of a survey design based on primarily closed-ended questions, administered to an availability sample of 31 South African translators drawn from the membership of the South African Translators' Institute (SATI), used as a sampling frame for the study. The survey was, in the first instance, designed to solicit respondents' opinions on which translation strategies they would most likely select to deal with particular ethical challenges. In order to better understand the factors affecting the selection of translation strategies, the impact of two translator factors (experience and age) and two text factors (text type and type of ethical problem) was investigated. In the second instance, the survey aimed to investigate why respondents selected particular strategies, and indirectly how they view their ethical responsibility. Following Chesterman's (2001) basic distinction, reasons for the selection of translation strategies were categorised as informed primarily by either personal or professional ethics. (The distinction drawn between personal and professional ethics in the study, and how it was communicated to respondents, are discussed in more detail in sections 2.3, 3.3.1 and 3.3.2.) In addition to the overall investigation of the role of personal and professional ethics, the study examined differences in the role of personal and professional ethics depending on the type of ethical problem, the type of text, respondent age, and different levels of translation experience.

In what follows, it should be kept in mind that findings reflect translator respondents' claims about how they would approach particular translation problems involving ethical challenges in certain hypothetical situations, and why they chose particular translation strategies. These claims may not correspond to actual translation practice. Furthermore, these claims were specifically solicited in the context of a survey investigating ethical challenges in translation (an aim which respondents were made aware of), and therefore respondents' answers may have been influenced by what is known in the social sciences as the "socially desirable response bias" - respondents" tendency to answer questions in a way that they perceive as meeting social expectations. Watson, Teague and Papamarcos (2007:12) point out that "[b]ecause all respondents have, to varying degrees, a need to see themselves as moral and competent people, self-reports of personal morality and ethics are especially vulnerable to response bias". The ways in which the possible effects of the socially desirable response bias were minimised in this study are discussed in more detail in section 3.1 , but its potential influence should be kept in mind throughout the discussion.

\section{Literature review}

\subsection{Professional ethics in translation}

For many researchers in the field of translation ethics, the focus has been on demarcating the professional roles, responsibilities and rights of the translator. As has already been pointed out, Chesterman (2001:152) sees a clear distinction between personal and professional ethics:

I suggest that understanding is the highest value for translators - albeit in a wide and varied sense. All other relevant professional values - truth, clarity, loyalty, trust - are 
subordinate to understanding. This, I submit, is the defining limit of a translator's professional ethics, and also of their professional responsibility, the responsibility of their practice. The translator might of course feel personally responsible for the consequences of this understanding, and this feeling of personal responsibility might well affect their decisions about whether, or how, to translate [...] What communicating parties do with their resultant understanding is a matter of their own ethical principles - whether they use it to cooperate, for good or evil, or whatever.

In other words, for Chesterman, there is a clear distinction between personal and professional ethics, and any wider socio-cultural or even activist role that the translator may play he sees as outside the domain of professional ethics, per se, even though translators may of course choose to allow their personal ethics to influence the way in which they apply their professional ethics.

Chesterman (2001) puts forward four models of translation ethics: an ethics of representation, an ethics of service, an ethics of communication, and norm-based ethics. As far as the ethics of representation is concerned, this is based on loyalty towards the source text, as well as loyalty towards ethical representation of the Other (Chesterman 2001:139-140). An ethics of service is founded on a view of translation as a service rendered to a client, and in this view ethical behaviour equates to meeting the ideals of rendering a professional service (Chesterman 2001:140). An ethics of communication is less concerned with representation of the source text, or meeting the client's requirements; rather it is founded on the principle of enabling communication and cooperation. This is also the basis of Pym's $(2000,2012)$ view on ethics, discussed in more detail below. Lastly, Chesterman distinguishes a norm-based ethics, which is premised on the idea that norms encode the ethical values held at a particular time in a particular society, and that ethical behaviour therefore equates to behaving in accordance with these norms as socially sanctioned expectations (Chesterman 2001:141).

Chesterman (2001) argues that these four models are each, in their own way, problematic, and may furthermore be incompatible, since they highlight different ethical values, and are based on different basic kinds of ethics. The service and norm-based ethics are primarily contractual ethics, whereas the representation and communication models are based on utilitarian ethics (Chesterman 2001:143). Chesterman's (2001) own formulation of an ethical code for translation is based on a kind of virtue ethics, where the most important virtue is the commitment to striving for excellence in translation, to being a good translator (Chesterman 2001:147), combined with other virtues such as fairness, truthfulness, trustworthiness, empathy and determination (Chesterman 2001:147).

Pym (2000, 2012), too, believes that there are limits to the translator's professional responsibility: "In general, then, there is no need for translators to claim (or be attributed with) any commitment to the content of what they are translating. To that extent they are translators, not authors, and they have no need to sign up en masse for this week's good causes" (Pym 2012:67). He argues his point from within formal pragmatics, stating that authorship involves a particular kind of responsibility within communication acts, a kind of responsibility not shared by translators (Pym 2012:62).

However, this does not mean that translators have no responsibility at all. Translators have professional responsibilities, which Pym (2012:76-81) sets out as having essentially three dimensions: responsibility to the content of the text, responsibility to the client, and 
responsibility to the profession. These three responsibilities echo the conventional delimitation of professional codes of ethics, and also overlap to a large degree with Chesterman's (2001) ethics of representation and ethics of service.

However, the ethical responsibilities of translators may also be cast within a somewhat wider frame, that of cooperation (Pym 2000, 2012:134-163). For Pym (2012:134), the ultimate value of a translation (as for all other forms of communicative interaction) is the measure of cooperation that it enables, or the amount of mutual benefit that it generates for all involved in the interaction. This is, in essence, a teleological approach to translator ethics, in which the translator, as intercultural-communication expert, has the responsibility of optimising cooperation between communicating parties. However, it does appear that this optimisation is circumscribed to the more immediate interaction between participating parties - for Pym (2000:184), translational ethics have less to do with "distant authors and unforeseen readers", and more to do with "the interaction between a translator, a client, an editor, a rate of pay, an image of immediate reception, a distribution network, and the intercultural space - the overlap of cultures - where all those professional and commercial elements impinge on each other". In other words, translation functions to facilitate intercultural cooperation in the immediate context of translation, which may have a cumulative effect, but the potential future large-scale socio-cultural and -political effects of translation are not the responsibility of the translator.

These types of ideas typically inform codes of ethics (such as those listed in the introductory section to the article), which focus on this immediate context within which a translation is produced, as well as the translator's responsibility towards his/her profession - which may be viewed as a kind of cumulative extension of these immediate contexts of translation. However, various translation scholars have pointed out that such codes of ethics, with their emphasis on accuracy, neutrality, fidelity, and service obligations, are problematic. According to Tymoczko (2007:32), such emphases efface "larger spheres of geopolitical responsibility to communities and the world". In other words, codes of ethics typically consider the agency of the translator only in the immediate professional context, but do not consider the translator's agency "in the evolving social, political and cultural configurations that make up society" (Hermans 2009:97). Taking the argument one step further, Baker (2011:274) argues that professional codes of ethics may in fact allow translators to shirk the implications of their socio-political ethical responsibilities by allowing them to "hide" behind the excuse of professionalism, thus turning "translators into unthinking cogs in the wheel of an established social system rather than reflective and ethically responsible citizens" (Baker 2011:284).

The above suggests that part of the translator's professional (and personal) ethics should be to continually question concepts of professional ethics as they are encoded in codes of conduct. Such questioning lies at the root of the broader socio-cultural approach to ethics, which sees the translator as an active and activist agent in the process of brokering individual and collective intercultural relationships in a world characterised by injustice and power imbalances.

\subsection{Activism and ethics}

Koskinen (2000:9) points out that redefinitions of the role of the translator since the 1990s have played a deciding role in shifting the view of ethics away from fidelity. In this view, the translator has agency, can make choices, and can be held accountable for these choices and their results within the wider socio-cultural context (Hermans 2009:93). The implication is that the 
translator, by definition, must assume responsibility for the consequences of his/her translation in the world, a view that stands in contrast to Chesterman's (2001) and Pym's (2012) argument that there must be limits to the translator's responsibility for such consequences. In this opposing view, translation (and by implication translators) "retains a responsibility to the future of target societies" (Gouanvic 2001:209). Some critics arguing this point have done so from a more general position intrinsic to translation studies, while others have taken up positions from extrinsic ideological paradigms imported into translation studies, such as feminism and postcolonialism.

Tymoczcko (2007:314-315) explicitly links her project arguing for changes in the conceptualisation of translation to a greater emphasis on the agency of translators:

A better understanding of the openness of translation as conceptualized in an international context can foster on the local level a habitual sense of confidence in and performance of translators' prerogatives and responsibilities in making meaning, in constructing culture, in acknowledging ideological aspects of their constructions, in formulating representations, in initiating transculturations, in promoting difference, in taking activist stands, and in introducing newness into the world.

For Tymoczko (2007), therefore, translational ethics is a matter of the agency of the translator in the wider socio-cultural and ideological sense. This agency, with its greater visibility, freedom and creativity, is not an end in itself - it brings with it greater ethical responsibility (Tymoczko 2007:316). Tymoczko (2007:315) sees this ethical responsibility, in part, as one of enabling and foregrounding difference. Her view of translational ethics is therefore, by its nature, an activist one, and she takes Chesterman (2001) to task for the way in which he effaces this aspect of translation from his proposal for an ethics of translation (Tymoczko 2007:320). ${ }^{2}$

This call for an activist translation ethics that works towards creating "a more just world where difference is welcome" (Tymoczko 2007:232) becomes more urgent against the background of globalised translational exchange, a point also argued by Cronin (2003) (see above). Venuti's $(1998,2008)$ work has been a consistent engagement with the ethics of translation in this broader sense, informed by the stance that translation is, innately, a violent activity, since, by its nature, it forcibly must re-place the foreign text into a receiving language and culture (Venuti 2008:14). However, Venuti also posits that this violence can, and must, be managed in terms of degree and direction (Venuti 2008:15). It is at this point that the concept of foreignising translation as the ethical choice emerges:

I want to suggest that insofar as foreignizing translation seeks to restrain the ethnocentric violence of translation, it is highly desirable today, a strategic cultural intervention in the current state of world affairs, pitched against the hegemonic English-language nations and the unequal cultural exchanges in which they engage their global others. (Venuti 2008:16)

\footnotetext{
${ }^{2}$ Pym (2012:87-88), however, takes a more sober view of the potential activist role of translators, cautioning that the realities of translators' often limited agency within the web of asymmetrical power relationships surrounding translation may not allow them to choose actions that will bring about change in the world. As he puts it: "Asking a translator to save the world is sometimes like asking an infant to read" (Pym 2012:88).
} 
Foreignisation (and domestication) are thus ethical attitudes (Venuti 2008:19), and fluency and resistancy may be regarded as discursive features of translation strategies linked (in potentially complex ways) to these ethical attitudes. The same kind of emphasis on foreignisation as the ethical translation choice to resist the effacement of difference (and the translator) that is the consequence of adherence to fluent strategies in pursuit of domestication, is also evident in the work of some translation scholars working explicitly in the postcolonial paradigm, and to some degree in the work of feminist translation scholars. ${ }^{3}$

\subsection{The distinction between personal and professional ethics}

Against the background provided in the preceding two sections, this study draws a basic distinction between professional and personal ethics, which are defined primarily by the kind of subjectivity from where the ethical motivation is articulated.

Professional ethics is defined in the narrower sense outlined by Chesterman (2001) and Pym (2012:76-81), circumscribing an ethics informed by the immediate professional context in which the translation is commissioned and produced. Professional ethics is codified in codes of ethics or conduct, and constitutes an articulation of ethical obligations that is determined by an external locus of control - the profession and its associated norms and expectations. Professional ethics is based on the interests of the profession, viewed impersonally, and elides the individual and personal (see Pym 2012:70). Professional ethics is thus expressed from a professional subject position.

In contrast, personal ethics is founded on a locus of control within the translator as person or individual. It is therefore more subjective, and involves the translator's articulation of an ethical motivation that is centred on his/her own beliefs. These beliefs may involve personal morality, but may also extend to the translator's conception of his/her own role and agency in the world, which are expressed from a personal rather than professional subjectivity.

\section{Methodology}

\subsection{Overview and general comments on research design}

The survey method of data collection, as opposed to, for example, interviews or focus-group discussions, was selected for a number of reasons. The most important consideration was the need to obviate the effects of the socially desirable response bias. Interviews and focus-group discussions involve personal contact between the researcher and the participant, and therefore strengthen the effect of the socially desirable response bias. In contrast, the survey design allows complete anonymity and a large degree of impersonality, which alleviate (though obviously do not completely eliminate) the potential effect of the socially desirable response bias.

This advantage, of course, is offset by the disadvantage of less opportunity to gather more nuanced data. Interviews or focus-group discussions generally yield richer and more finegrained data, particularly important in the context of complex research questions such as that of ethics, while surveys tend to generate data that are easier to classify, but lack subtlety and

\footnotetext{
${ }^{3}$ See, for example, Santaemilia (2005), Simon (1996) and Von Flotow $(1997,2011)$ on feminist translation theory and practice; and Bassnett and Trivedi (1999), Cronin (1996), Niranjana (1992), Spivak (2012/1992) and Tymoczko (1999) on postcolonialist approaches to translation.
} 
gradation. However, for the purpose of this study, the loss of more multi-layered data was viewed as a necessary cost of minimising the face-threatening context of the data collection.

In the sections that follow, the methodology of the research is described with particular attention to the selection of texts used as basis for the questionnaire, and the way in which the multiplechoice questions used to investigate (a) the choice of translation strategies and (b) the motivation for these choices, were constructed. The sampling of respondents and the data collection are also discussed. The meta-categories used for the analysis of the data are briefly outlined, and the ways in which the data were analysed are specified in more detail.

\subsection{Text sampling}

The survey was designed around authentic texts reflecting realistic ethical problems that translators may encounter. The first step was, therefore, the selection of texts. For the purposes of the study, four categories of problematic content were selected: sexism, racism, crude or obscene language, and content that may potentially be deemed unsuitable for (or offensive to) a particular target audience (for reasons other than racism, sexism or crude language). The study was limited to these four categories because of their representativeness of the kinds of ethical problems translators might typically encounter. Two to three texts per type of problematic content were selected on the basis of availability and suitability.

Since the investigation also sought to explore the potential effect of text type on the selection of translation strategies and the role of personal and professional ethics, four different text types were included: academic writing, mass-media texts (specifically magazine, newspaper and blog texts), literary texts (including prose, poetry and song lyrics), and children's literature.

The chronological distribution of the texts was an additional concern. Some chronological variation was introduced to investigate the potential effects of translators' perceptions of older versus more contemporary texts. Table 1 summarises the distribution of the texts according to the ethical problem, text type and chronology.

Table 1. Summary of texts used in the survey

\begin{tabular}{|c|c|c|c|}
\hline Text & Ethical problem & Text type & $\begin{array}{c}\text { Publication } \\
\text { date }\end{array}$ \\
\hline $\begin{array}{l}\text { Text } 1 \\
\text { Text } 2\end{array}$ & $\begin{array}{l}\text { Sexism } \\
\text { Sexism }\end{array}$ & $\begin{array}{l}\text { Academic } \\
\text { Mass media (printed media) }\end{array}$ & $\begin{array}{l}1992 \\
2003\end{array}$ \\
\hline Text 3 & Racism & Literature (song lyrics) & 1928 \\
\hline Text 4 & Racism & Mass media (online media) & 2011 \\
\hline Text 5 & Racism & Literature (fiction) & 1918/1949 \\
\hline $\begin{array}{l}\text { Text } 6 \\
\text { Text } 7\end{array}$ & $\begin{array}{l}\text { Crude language } \\
\text { Crude language }\end{array}$ & $\begin{array}{l}\text { Literature (fiction) } \\
\text { Mass media (online/social media) }\end{array}$ & $\begin{array}{l}2006 \\
2011\end{array}$ \\
\hline Text 8 & $\begin{array}{l}\text { Inappropriate, } \\
\text { potentially } \\
\text { offensive content }\end{array}$ & Children's literature (picturebook) & 2003 \\
\hline Text 9 & $\begin{array}{l}\text { Inappropriate, } \\
\text { potentially } \\
\text { offensive content }\end{array}$ & Literature (poetry) & 1984 \\
\hline
\end{tabular}


Text 1 is an extract from an academic paper presented at a symposium, and posed ethical difficulties because the noun "man" and the pronoun "he" is used throughout to refer to humanity, thus creating gendered imagery that may be offensive. In terms of function, academic texts are mostly informative and referential. Because of this informative function, and the fact that the text was evidently produced by a highly literate author and aimed at an equally highly literate audience, it was expected that respondents would follow the source text closely or adapt it only slightly.

Text 2 is a section of an article from a South African women's magazine. The article is founded on certain stereotypical assumptions about femininity, and generalises about what makes a woman happy (for example, buying shoes, underwear and lipstick, and "smooching her man"). This text is a mass-media text in printed form. The function of the text is vocative, or conative, impressing certain notions about femininity upon the readers. Translators may therefore have felt more compelled to act on behalf of the reader than in the case of the informative text (Text 1) discussed above. However, since the typical reader of this type of women's magazine probably shares the magazine's definition of femininity, professional ethics would have dictated that the translator translate accordingly, even if she found the content offensive from a personal point of view. To a large degree, however, this decision would be dependent on the strength of the translator's personal feelings about gender stereotyping.

Text 3 is the first part of the lyrics of the song "Let's Do It (Let's Fall In Love)" written by Cole Porter in 1928 and recorded by (amongst others) Billie Holliday in the 1940s. These lyrics include ethnic labelling, referring to "Chinks" and "Japs" - omitted in many later recordings of the song. This text's function is expressive as well as aesthetic or poetic, and thus its primary function is the creative expression of the author, and the exploitation of the creative possibilities of the medium itself. Therefore, it was foreseen that the respondents might be inclined to translate this text literally in an effort to remain loyal to the author's creative expression. Also, the fact that the song is removed both in time and space from the present context, may have predisposed respondents to favour faithful translation, since this is the only translation strategy that allows the translator to accurately retain the cultural connotations of the particular era.

Text 4 is another mass-media text, but this time from online rather than printed media. This text consists of extracts from a newspaper article written by Andile Mngxitama. The text expounds the idea that black people cannot be racist because white people invented racism to oppress black people, and has a dual expressive and vocative function. Because racism is an especially charged topic in the South African context, and because the text deals with issues that are currently topical in South African society, it was expected that many of the respondents would find the text particularly problematic. It was foreseen that respondents would opt to refuse to translate the text on the grounds of either their own personal beliefs, or their belief that ideas such as these are harmful to projects of nation-building and reconciliation.

Text 5 is an extract from a short story titled "Architecture" by Crosbie Garstin, first published in 1918, and later re-published in Veld-trails and Pavements: An Anthology of South African Short Stories (edited by H.C. Bosman and C. Bredell) in 1949. The text contains a number of racial slurs. The text has an aesthetic function, but in a way it is also an informative text, reflecting the racist ideological assumptions underpinning colonialism and apartheid. The expectation was that translators would choose a more literal translation, as a consequence of the aesthetic function and historical value of the text. 
Text 6 is an extract from a popular contemporary novel for adults, A Long Way Down, by Nick Hornby, published in 2006. It is thus also a literary text that fulfils expressive and aesthetic functions. The text contains many obscenities, and it was foreseen that some respondents would find this offensive on a personal level. However, because of the text type and the function of the text, it was foreseen that respondents would most likely translate it literally or only slightly adapt the expletives to less offensive versions.

Text 7 is an extract from a personal parenting blog, and it expresses the author's frustrations as a result of the awkward size of the pregnant body. The author uses strong language to express her frustration, which some might regard as unsuited to the idealised image of pregnancy often depicted in the media. This text has a primarily expressive function, and it was foreseen that translators may well choose to retain the crude language, based on their professional ethics of respect for the author. However, depending on the strength of respondents' personal feelings about the crude language used in this context, they might well have felt uncomfortable enough with the text to choose adaptation or omission.

Text 8 is the first of two texts in the category dealing with inappropriate, potentially offensive content. It is taken from a well-known children's picturebook (Mummy Never Told Me) by Babette Cole, dealing with "secrets" that parents keep from their children. The selected pages dealt with children's questions about same-sex relationships, and in translating it, respondents would have to decide whether the content is appropriate for young children. Children's literature texts typically combine expressive, aesthetic and conative functions - such texts almost always try to inculcate some kind of value in the child, in this case, the value of tolerance of difference. Since adults generally have distinct ideas about what is appropriate for children, it was expected that an emotional rather than a professional response would be elicited. It was predicted that some respondents might be in favour of educating children about this topic and would thus choose to translate literally, while other translators might find the topic inappropriate for the target audience and thus refuse to translate.

The last text in the questionnaire, Text 9, is the poem "Student Love" by Allen Ginsberg, first published in 1984. Ginsberg is famous for his explicit descriptions of relationships between men, and this poem is about a love affair with a much younger boy. This text has a poetic or aesthetic function, as well as an expressive function, made more pertinent by the autobiographical qualities of Ginsberg's poetry. It was expected that many of the respondents would find this text offensive, and might refuse to translate rather than adapt the text because it would be virtually impossible to adapt it. However, it was foreseen that respondents also might opt to translate the text fairly literally in an effort to respect the author's creative expression. Again, the strength of respondents' personal feelings on the topic would be a deciding factor.

All texts were presented in English, and respondents were asked to consider a specific, clearly described translation situation involving translation into whichever language they habitually worked in. More information about the contextualisations used is provided in section 3.3.2.

\subsection{Questionnaire design}

The questionnaire comprised (a) an introductory component, including a cover letter, a consent form, a section soliciting biographical data, and an explanatory section; and (b) the multiplechoice component, divided into sections for each type of problematic content outlined above. 


\subsubsection{Introductory component}

In the cover letter, the distinction between personal and professional ethics was explained in the following way:

Personal ethics can be defined as a person's intuition, religion, values, morals and beliefs. Professional ethics refer to the norms, values and principles that guide the translation profession, the rules governing the translator's conduct and the obligation to not harm the client, author and/or target audience.

It should therefore be noted that translators were alerted to the distinction between personal and professional ethics, which was defined in a very particular way, though there is (both intentionally and unavoidably) some ambiguity in the definitions. The categories of personal and professional ethics were, however, not explicitly linked to any of the multiple-choice items, and these categories were therefore used in a meta-analytical way for the analysis of the data.

The introductory component further included a consent form, which also guaranteed anonymity as a condition of participation. The biographical data solicited included age, gender, years of experience as a translator, language combination, and work environment. Lastly, the introductory section included an explanatory section in which examples were used to define the different translation strategies presented as options in the multiple-choice component.

\subsubsection{Multiple-choice component}

The multiple-choice component was divided into sections dealing with the different types of problematic content, each of which followed a set format. Each section contained two or three texts. A contextualisation was provided for each text in the questionnaire, which indicated the origin of the text, the purpose of translating it, and the potential target audience. The aim of the contextualisation was to create a scenario for an authentic translation situation, and these translation situations were designed to be as neutral as possible. In other words, the translation situations were formulated in such a way as to avoid leading the respondents to a particular translation choice. ${ }^{4}$ The contextualisation for each of the texts is provided in Table 2.

Table 2. Contextualisation provided for each text

\begin{tabular}{|l|l|}
\hline Text & Contextualisation provided \\
\hline Text 1 & $\begin{array}{l}\text { This text is an extract from a paper presented at a symposium on the } \\
\text { relationship between humanity and technology. This paper is to be } \\
\text { translated to be discussed at a symposium on the developments in } \\
\text { humanities as a field of study. It is to be translated into Afrikaans and } \\
\text { African languages to aid the interpreters. }\end{array}$ \\
\hline Text 2 & $\begin{array}{l}\text { This text comes from a women's magazine and deals with what it } \\
\text { means to be a woman and what makes a woman happy. The text is to } \\
\text { be translated into African languages and Afrikaans for 'sister' }\end{array}$ \\
\hline
\end{tabular}

\footnotetext{
${ }^{4}$ Against the background of the reality of the South African publishing industry, the attempt to create "realistic" translation situations sometimes did result in target-culture situations that were somewhat different from the original context of publication, which may have affected respondents' choices. These matters are taken into consideration in the discussion of findings.
} 


\begin{tabular}{|l|l|}
\hline & $\begin{array}{l}\text { magazines' websites. The target audience is women between the ages } \\
\text { of } 20 \text { and } 40 .\end{array}$ \\
\hline Text 3 & $\begin{array}{l}\text { This text is the first part of the lyrics of a song written by Cole Porter } \\
\text { in 1928, and recorded by Billie Holliday in the 1940s. It is to be } \\
\text { translated into Afrikaans and African languages for a multilingual } \\
\text { book of song lyrics. }\end{array}$ \\
\hline Text 4 & $\begin{array}{l}\text { This text is made up of sections from an article by a radical South } \\
\text { African activist for a well-known newspaper. The text is to be } \\
\text { translated into Afrikaans and African languages for the newspaper's } \\
\text { 'sister' websites. }\end{array}$ \\
\hline Text 5 & $\begin{array}{l}\text { The following extract comes from an anthology of South African } \\
\text { stories. It is to be translated into Afrikaans and African languages for } \\
\text { a new edition of South African tales. }\end{array}$ \\
\hline Text 6 & $\begin{array}{l}\text { This text is a section from a popular contemporary novel for adults. } \\
\text { The book must be translated into African languages and Afrikaans } \\
\text { for a South African audience. }\end{array}$ \\
\hline Text 7 & $\begin{array}{l}\text { This text was taken from a parenting blog. The text is to be translated } \\
\text { into African languages and Afrikaans for a magazine on pregnancy } \\
\text { and childbirth for the modern woman. }\end{array}$ \\
\hline $\begin{array}{l}\text { These pages were taken from a children's book dealing with 'secrets' } \\
\text { that parents keep from their children. The text must be translated into } \\
\text { African languages and Afrikaans for children between the ages of } 8 \\
\text { and 10 as a prescribed school reading book. }\end{array}$ \\
\hline Text 9 & $\begin{array}{l}\text { This text is a poem written by a male poet about a love affair with a } \\
\text { much younger boy. The poem is to be translated into Afrikaans and } \\
\text { African languages as part of an anthology of influential poets for first- } \\
\text { year university students. }\end{array}$ \\
\hline
\end{tabular}

The contextualisation was followed by the text or an extract of the text. For each text, respondents were provided with four standard translation strategies, and four pre-formulated possible reasons for making their choice. Respondents were also provided with the option to formulate their own motivation for their translation choice, in a blank space provided.

Baker (2006:105) comments that translators have recourse to a variety of more or less explicit strategies to replicate, strengthen, neutralise or ameliorate the ideological discourses and positions encoded in a text. In this study, this variety of potential strategies was reduced to four basic categories, chosen as representative of the most likely strategies for translating problematic content. ${ }^{5}$ Respondents were asked to choose the option they thought they would most likely select in a real-life situation. These translation strategies were explicitly defined in an example section that preceded the actual questionnaire, together with some examples of the kinds of translations that might be produced by a particular translation strategy.

The first translation strategy was labelled "literal translation", and was defined as a strategy in which the potentially offensive content is largely retained. The literal translation strategy is a direct, fairly literal translation that retains all the offensive detail in the translation, though it may involve substituting some culture-specific terms with others that carry the same

\footnotetext{
${ }^{5}$ None of the respondents commented on the translation strategies provided or recommended another strategy.
} 
communicative effect. However, the aim of this method is to retain both the denotative and connotative meaning of the source text in the translation. The strategy defined as "literal translation" therefore reflects the common perception that faithfulness to the source text is the ethically responsible translation strategy. The second translation strategy was labelled "neutralising adaptation". In this strategy the translator opts to adjust the content so that the problematic material is adapted in the translation to mitigate some of the potentially offensive effect. However, there is still some attempt to render some of the contextual meaning of the source text, even if in an ameliorated version. The third translation strategy was defined as "omission", which involves omitting the problematic content altogether, or replacing the problematic content with a completely neutral formulation. The last translation option was "refusal to translate", which meant that the respondent would not accept the commission. ${ }^{6}$

In the explanatory section, respondents were provided with the definitions above, as well as examples of the kinds of translations each strategy would produce, in the standard format of the questionnaire. While the first part of each question dealt with the choice of translation strategy, the second dealt with respondents' motivation for their choice. In this section, the basic tensions between personal and professional ethics were explored, with the two types of ethics defined (as discussed in section 2.3) as dependent on the subject position and frame of reference from where the motivation is articulated. For each text in the questionnaire, four possible reasons for the selection of the translation strategy were supplied. These reasons were tailored to each text, and for each text two reasons related to personal ethics and two related to professional ethics were formulated. It should be noted that these reasons were not indicated as relating to personal or professional ethics in the questionnaire itself - in other words, the distinction between personal and professional ethics is a meta-category used for analysis only. Some options were included allowing respondents to disagree with the evaluation of the content as problematic. Furthermore, some motivations were positive, and others negative. Three examples of motivations (and their categorisations, used for the analysis) are provided in Table 3.

Table 3. Examples of motivations provided for translation choices, and their categorisation

\begin{tabular}{|l|l|l|l|}
\hline Text & $\begin{array}{l}\text { Ethical } \\
\text { challenge }\end{array}$ & Motivations provided & $\begin{array}{l}\text { Category of motivation } \\
\text { (used for analysis) }\end{array}$ \\
\hline 1 & Sexism & 1. It offends my feminist beliefs. & Personal \\
\cline { 3 - 4 } & $\begin{array}{l}\text { 2. As a professional, I should represent } \\
\text { the client whether the text offends me } \\
\text { or not. }\end{array}$ & Professional \\
\cline { 3 - 4 } & $\begin{array}{l}\text { 3. I have no problem with 'man' } \\
\text { representing men and women. }\end{array}$ & Personal \\
\cline { 3 - 4 } & $\begin{array}{l}\text { 4. It is the policy of the organisation I } \\
\text { work for to translate without bias. }\end{array}$ & Professional \\
\hline
\end{tabular}

\footnotetext{
${ }^{6}$ As Pym (2012:103) points out, the decision to translate is, in fact, the first decision the translator is responsible for - but this statement should be seen against the background that, in reality, translators do not always have the necessary financial or professional independence (or agency) to make such a decision. In this study the constraints of the real world are, of course, absent, allowing respondents to imagine a situation in which they are free of financial incentives or contractual obligations to translate.
} 


\begin{tabular}{|c|c|c|c|}
\hline \multirow[t]{4}{*}{4} & \multirow[t]{4}{*}{ Racism } & $\begin{array}{l}\text { 1. I think this text represents freedom } \\
\text { of speech and think it is inspiring. }\end{array}$ & Personal \\
\hline & & $\begin{array}{l}\text { 2. I must adhere to SATI's professional } \\
\text { code of conduct. }\end{array}$ & Professional \\
\hline & & $\begin{array}{l}\text { 3. I find this text offensive and struggle } \\
\text { to be objective. }\end{array}$ & Personal \\
\hline & & $\begin{array}{l}\text { 4. It is my job to transfer the author's } \\
\text { intended meaning as faithfully as } \\
\text { possible. }\end{array}$ & Professional \\
\hline \multirow[t]{4}{*}{8} & \multirow{4}{*}{$\begin{array}{l}\text { Inappropriate, } \\
\text { potentially } \\
\text { offensive } \\
\text { content }\end{array}$} & $\begin{array}{l}\text { 1. I do not think this information is } \\
\text { appropriate for children. }\end{array}$ & Personal \\
\hline & & $\begin{array}{l}\text { 2. It is my professional duty as a } \\
\text { gatekeeper to protect the target } \\
\text { audience. }\end{array}$ & Professional \\
\hline & & $\begin{array}{l}\text { 3. I believe it is important to be open } \\
\text { about sexual preferences. }\end{array}$ & Personal \\
\hline & & $\begin{array}{l}\text { 4. I have to be the author's voice, so it } \\
\text { is expected of me (by my employer) to } \\
\text { translate faithfully. }\end{array}$ & Professional \\
\hline
\end{tabular}

In addition, respondents could select "Other" as motivation for their translation choice, and formulate their own reason. About half of the participants made use of this option for one or more questions when completing the questionnaire. In the analysis of the data, such instances were also coded as motivated primarily either by personal or professional ethics, for the sake of the quantitative analysis. However, some of these comments are also discussed qualitatively in section 4.

An example of a self-formulated motivation clearly strongly motivated by personal ethics is the following, in response to Text 9:

I would have refused to translate this text because as far as I'm concerned it 'propagates' something that - apart from the fact that I personally find it offensive and believe it is a sin (but not a 'bigger' sin than any other, at least not warranting hating the sinner) - could 'inspire' readers to mess up some child's life (whether boy or girl). Adults choose what they want to do, I suppose, but children should be respected and protected until such time as they can respect and protect themselves. I regard it as my job and my responsibility as a Christian, a mother, a teacher, a communicator and most of all as the voice of the voiceless and the defenceless not to help spread this kind of 'message' in ANY way.

Other respondents were far blunter in formulating their personal motivations, as in the following examples:

The text contains factual inaccuracies which I will clearly not be able to negotiate about, seeing that the author is an idiot. (Text 4)

Just the kind of text I wouldn’t want to waste my time on - it's plainly ridiculous. (Text 2) 
Now THIS is really sexist crap, the sort of thing popular magazines thrive on. Don't work for them... (Text 2)

It should, however, be noted that some respondents also expressed positive valuations of texts from their personal frame of reference as motivation for translation choices, as in the case of Text 8. One participant formulated his/her motivation for a literal translation of this text as follows:

It is important for children to learn about same-sex relationships from some 'official', 'authoritative' source like a school book or teacher, rather than from schoolyard sensationalism.

Self-formulated motivations based on professional ethics, in contrast, frequently invoked professional standards of accuracy, loyalty, fidelity, text type, and target audience. One participant, commenting on his/her decision to select literal translation for Text 2, provided the following motivation:

I'd see this as probably what readers of women's magazines would be buying the magazines for, hence although I personally don't agree with all the items, I wouldn't alter anything. The context, i.e. both the type of publication and especially the target audience, is the key here.

A number of respondents cited their professional assessment of text type as a motivation for their choices, as in the following example (for Text 9):

Another literary item, where faithfulness to the text at all levels of its discourse is essential - all the more so in the case of poetry. One might as well not include the poem in the anthology, rather than falsify it with a neutralising translation.

\subsection{Participant sampling and data collection}

A non-probability sampling method was used, and specifically a combination of purposive, expert and availability sampling. SATI was approached, and asked to distribute the covering letter and questionnaire among their membership, via e-mail. ${ }^{7}$ Although the sampling was not random, there was no pre-selected or targeted recruitment of specific participants. The final sample consisted of 31 respondents.

According to Marion Boers, executive director of SATI, the institute has about 750 individual members (personal communication, 11 July 2013), and the sample therefore constitutes $4 \%$ of SATI's total membership. ${ }^{8}$ However, it should be kept in mind that SATI represents not only translators, but also other language professions, such as interpreters and editors. Furthermore, this response rate is very similar to that of other studies making use of SATI as a sampling

\footnotetext{
${ }^{7}$ The use of SATI (a professional body for language workers) as the sampling frame was not informed by any exclusionary view of professionalism (see Pym 2012:81-86); rather it was intended to provide access to a population identifying themselves as language workers and who generate at least part of their income from translation.

${ }^{8}$ The data for this study were collected in September 2011. According to Boers, the membership demographics from 2011 to 2013 have remained very similar (personal communication, 11 July 2013).
} 
frame (see, for example, Kruger and Bevan-Dye 2010, Law and Kruger 2008). It should also be kept in mind that the questionnaire involved 9 texts, which means that the data analysis is based on a total of 279 data points. Because of the low number of respondents, and the fact that sampling was not strictly random, no inferential statistics were used in the analysis of the data, and only descriptive statistics are reported.

\subsection{Data processing}

The data from the questionnaires were coded and captured in Excel, and subsequently processed in Statistica version 10 (StatSoft Inc. 2011), using cross-tabulation. As a first step, descriptive statistics for the overall sample of texts and respondents were produced, considering translation strategies and type of motivation for strategies overall, as well as the relationship between the type of motivation for strategies and the selection of translation strategy. However, to enable more nuanced interpretation of the data, the effects of factors such as the type of ethical dilemma, the text type, and demographic factors also needed to be considered. To this end, the following factors were cross-tabulated:

- translation strategy per type of ethical challenge;

- motivation per type of ethical challenge;

- translation strategy per text type;

- motivation per text type;

- translation strategies per years' experience;

- motivation per years' experience;

- translation strategies per age, and

- motivation per age. ${ }^{9}$

\section{Findings and discussion}

\subsection{Sample description}

The sample consisted of 31 professional translators. About half the respondents were older than 45 , and the other half younger, yielding a representative age distribution. In terms of gender distribution, overwhelmingly more women than men participated in the survey, with a total of $81 \%$ of respondents being females. The fact that there was not a more balanced distribution of male and female respondents is not surprising, since translation in South Africa is a career dominated by women, and of SATI's membership, Boers (personal communication, 11 July 2013) notes that roughly $26 \%$ are males and $74 \%$ females. The sample therefore accurately represents the population, but the dominant representation of women should be taken into consideration in the interpretation of the findings.

There was a reasonable distribution of levels of experience, with the largest percentage of respondents (29\%) having 11 to 15 years' experience. With regard to the language pairs the respondents most frequently work in, the sample reflected very little diversity. It was expected that the English-to-Afrikaans and Afrikaans-to-English language pairs would feature strongly (and they do, with $36 \%$ and $29 \%$ of respondents, respectively, citing these combinations as the

\footnotetext{
${ }^{9}$ The effect of other demographic variables (such as gender and language) could not be investigated, due to limited variation in these variables in the sample of respondents.
} 
most frequent combination they work in). A total of $35 \%$ of respondents indicated that they work between English and European languages. None of the respondents worked in the language pair English to African languages.

While SATI aims to represent the interests of all language practitioners in South Africa, their membership is skewed in favour of Afrikaans/English translators. It is the case that, for complex reasons, there are generally fewer language practitioners working in African languages than in Afrikaans and English, but it is also the case that African-language practitioners do not have as strong representation in SATI as Afrikaans/English translators do. According to Boers (personal communication, 11 July 2013), about 45\% of SATI's members are Afrikaansspeaking, 25\% English-speaking and the rest cover the range of South African and world languages. This means that SATI's membership is more than $70 \%$ Afrikaans- and Englishspeaking, which does mean that the sample fairly accurately represents SATI's membership.

Generally, therefore, the sample adequately reflects the population of South African translators in terms of experience, gender and age. The only aspect in which the sample falls short of representativeness is in terms of language combinations (and by implication racial diversity), and this should be kept in mind in the interpretation of findings.

\subsection{Findings}

\subsubsection{Overall preferences}

In this study, respondents clearly favoured the literal translation strategy above all others, with $68 \%$ of all choices falling into this category (see Figure 1). This finding is in line with the traditional view (also reflected in most codes of ethics) that the translator is ethically obligated to remain faithful to the source text. The strategy of omission was selected least frequently, with only one respondent choosing this option for one of the texts, suggesting translators' disinclination to make radical alterations to the source text. The strategies of neutralising adaptation and refusal to translate were selected considerably less frequently, at $16 \%$ of the time each. It therefore appears that the idea of faithful translation as ethical translation, which is a touchstone of the traditional, narrower professional view of ethics, does, in fact, inform this group of translators' preferences for translation strategies.

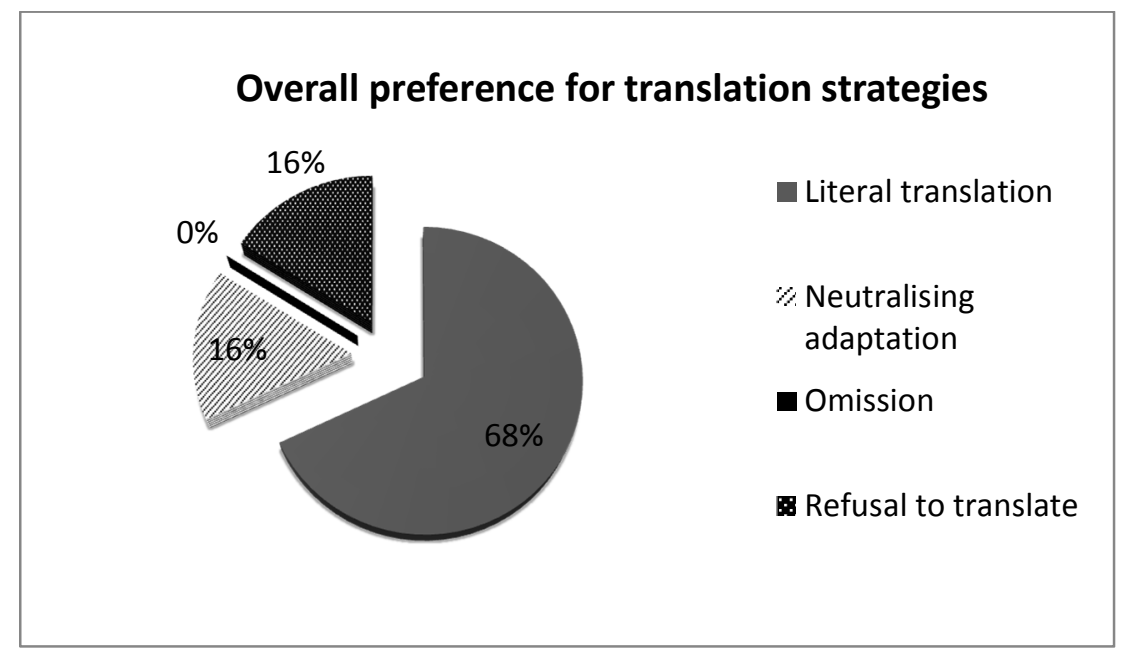

Figure 1. Percentage distribution of overall preferences for translation strategies 
In terms of the influence of personal and professional ethics on respondents' selection of particular translation strategies, it is clear that the two kinds of ethics both exert a strong, almost equal influence. Selected $51 \%$ of the time as motivation for choices of translation strategies, professional ethics is only marginally more influential than personal ethics in the decisionmaking process. It therefore seems as if personal ethics does play a substantial role in the decisions made when translating a text, and professional status does not suppress the tendency to articulate ethical motivations from a personal, rather than a professional, subject position and frame of reference. This is particularly evident in respondents' self-formulated motivations, which were frequently formulated from very distinct personal frameworks and subject positions, as is evident in the examples cited in section 3.3.2. Clearly, professionalism does not exclude an interplay between personal and professional ethics, as Pym (2012:80) also observes:

We know full well that professional subjectivity never suppresses individual subjectivity in the intimate space of doubt. The profession is a mask that smiles with confidence and assurance, ideally inspiring the same attitudes in others. If it can hide the individual, it is not less true that individuality can peek through the profession.

A last aspect investigated for the overall sample involved cross-tabulating the kind of ethical motivation with the translation strategy selected (see Figure 2). ${ }^{10}$

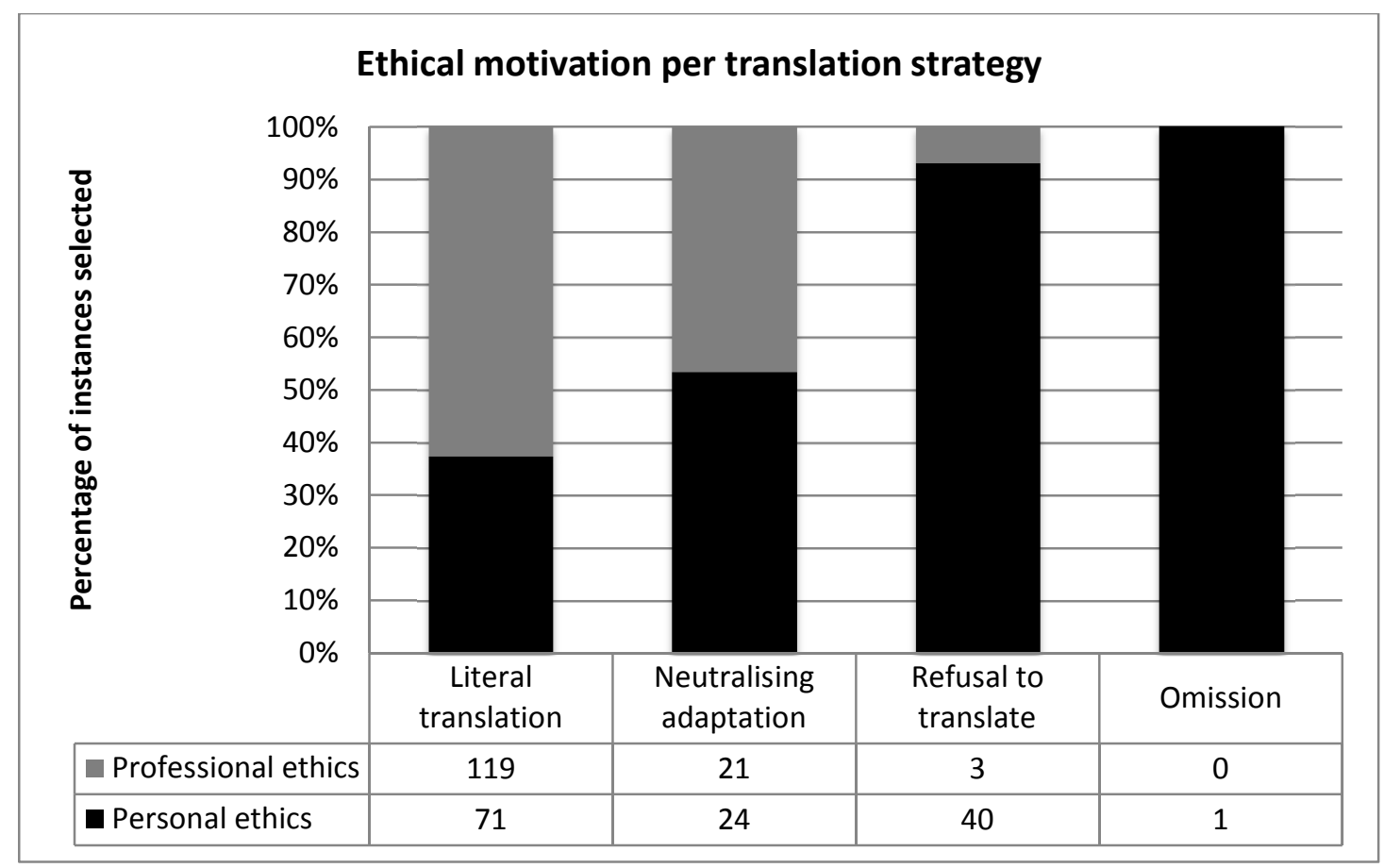

Figure 2. Number and percentage of instances personal and professional ethics selected as motivation per translation strategy

In this study, when respondents chose the literal translation strategy, it was generally motivated by professional rather than personal ethics, with professional ethics cited $63 \%$ of the time (119

\footnotetext{
${ }^{10}$ In this graph and in those that follow, the number of times a translation strategy or ethical motivation was selected is graphically depicted as a percentage of the total times, for each category on the horizontal axis, in order to standardise the scale. However, raw counts are also provided in the legend so as not to efface the numerical differences in the raw data for the different categories on the horizontal axis.
} 
out of 190 times) as motivation for this translation strategy, and personal ethics $37 \%$ of the time (71 out of 190 times). An example of a text which many of the respondents chose to translate literally was Text 5, the extract from an anthology of South African stories which demonstrates explicit racist ideology. Many of the respondents explained that, although the content clashed with their personal beliefs, it was a part of history that needed to be told and it was their duty to remain faithful to the source text. One respondent formulated his/her motivation in the following way:

[...] this literary text belongs to its author (as well as to its era) and should be accurately translated. However (and especially if the anthology were for children), I would suggest footnoting the word 'nigger' to indicate both that this historical usage is now considered insulting, and that the phrase is a misquotation of 'the world, the flesh, and the devil' - which makes it all the more offensive [...] but that this may [...] be an important part of the characterisation of one or other of the characters in the scene, thus, again, not to be tampered with by the translator of a literary text.

Another example of a text which many respondents chose to translate literally was Text 1, the extract from an academic paper using gendered terminology. Respondents explained that, as professionals, they should represent their client regardless of whether they are offended by this usage. However, it should also be borne in mind that respondents could, and did, select personal motivations for literal translation strategies (in 37\% of cases), so literal translation strategies ought not to be regarded as exclusively motivated by professional considerations. For example, in the case of Text 1 , many respondents motivated their choice of literal translation from a personal rather than a professional point of view, stating that they personally saw no problem with the usage of "man" to refer to both men and women, or as one respondent formulated it: "Besides, the use of 'man' here is not necessarily offensive unless you have a chip on your shoulder". 11

However, when the strategy of refusal to translate was chosen it was overwhelmingly the consequence of personal ethics, with personal ethics cited $93 \%$ of the time (40 out of 43 times) for this translation strategy, and professional ethics accounting for only $7 \%$ of motivations (3 out of 43 times). Some of the self-formulated motivations for such refusals have been reproduced in section 3.3.2. One of the texts which some of the respondents indicated they would refuse to translate was Text 4, a section from an article written by a radical South African activist about racism. Of course, the fact that none of the respondents were black should also be kept in mind in interpreting the findings for this text. Other texts which some respondents felt they would refuse to translate was Text 2, the magazine text that made generalisations about femininity, and Text 8, the extract from a children's book dealing with same-sex relationships. A number of respondents also indicated that they would refuse to translate Text 9 , the poem written by a male poet about a love affair with a younger boy. The respondents in most instances indicated that they were personally offended by the texts, and elected to refuse the translation because the text was in conflict with their personal beliefs - however, in some instances they also indicated that they would refuse to translate because they felt they needed to exercise their agency in acting on behalf of society or protecting the audience.

\footnotetext{
${ }^{11}$ A number of participants did comment that in translating to Afrikaans, "man" is generally rendered as "'n mens" (literally, 'a human'), which effectively solves at least one of the problems in the text. However, they generally did not consider the issue of pronoun usage in their comments, which is replicated in Afrikaans in the same way as in English.
} 
When the neutralising adaptation strategy was chosen, it was marginally more often as a consequence of personal rather than professional ethics, with personal ethics cited 24 times (or $53 \%$ of the time) and professional ethics cited 21 times (or $47 \%$ of the time). Based on these results, it may be proposed that the more drastic the action taken by the respondent, the more influential personal ethics are and the more likely the respondent is to articulate his/her motivation for the choice from a personal rather than professional subject position.

\subsubsection{The role of the type of ethical problem}

In order to explore whether there is a relationship between the type of ethical challenge or problematic content, and the selection of a particular translation strategy, the four translation strategies were cross-tabulated against the four types of problematic content (see Figure 3).

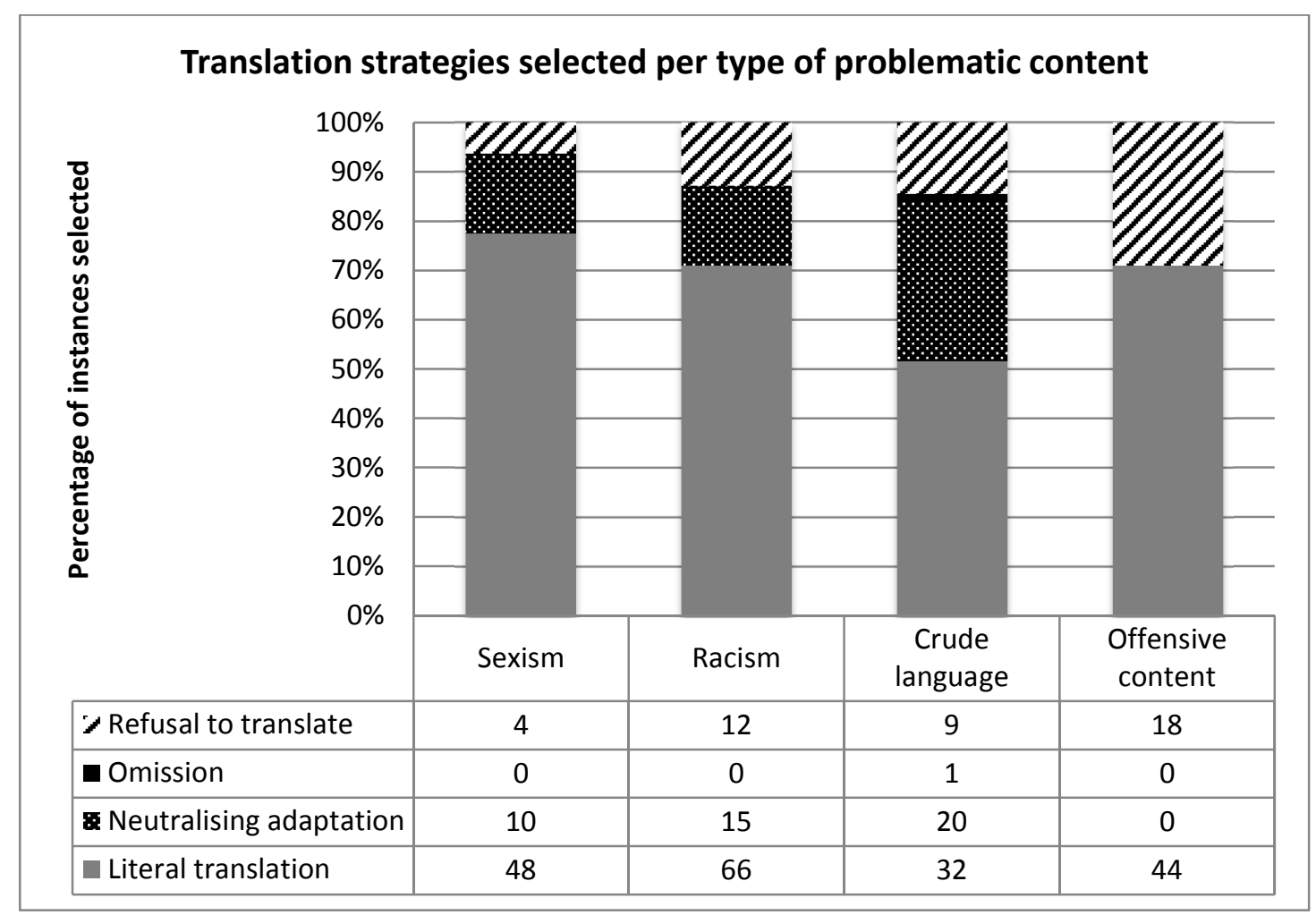

Figure 3. Number and percentage of times translation strategies chosen per type of problematic content

Although literal translation is clearly the most favoured strategy in all four categories of problematic content, for the category of crude language there is a smaller margin of difference between literal translation (selected 32 out of 62 instances, or $52 \%$ of the time) and neutralising adaptation (selected 20 out of 62 instances, or $32 \%$ of the time) than in the other categories, where the literal translation strategy dominates much more strongly. It appears that respondents were more willing to adapt or neutralise the potentially disagreeable effect of crude language than the potentially offensive elements of the other categories of problematic content. Crude language is therefore possibly considered more of a "surface" feature of a text, more open to manipulation by the translator, than other features which are viewed as more integral. There are interesting touchpoints here with research demonstrating translators' inclination to manipulate swearing and obscene language - by neutralisation or euphemisation, but also by intensification 
when necessary - based on their perception of the expectations and norms of the target audience (see, for example, Pérez Quintero and Toledano Buendía 2001, Taivalkoski-Shilov 2009). However, some caution should be used in interpreting the findings here - the contextualisation of one of the texts in this category (Text 7) involved a shift in medium (from blog text to print text) that may have affected respondents' selection of strategy. To illustrate the point, for the other (literary) text in this category (Text 6), 22 respondents (71\%) selected literal translation as the appropriate strategy, with 6 respondents (19\%) selecting neutralising adaptation, and 3 $(10 \%)$ selecting refusal to translate. For Text 7 , conversely, fewer respondents selected literal translation, and more neutralising adaptation. For this text, 10 respondents $(32 \%)$ selected literal translation, $14(45 \%)$ neutralising adaptation, 1 (3\%) omission, and $6(20 \%)$ refusal to translate. It is likely that the different strategy selection profiles for the two texts in this category are the consequence of their different content and functions, but it must also be assumed that the contextualisation played at least some role in respondents' choice of translation strategy, suggesting the importance of translators' assessment of audience needs and decisions about translation strategies. One respondent's self-formulated motivation for her decision to use neutralising adaptation for Text 7 makes this clear (though it should be noted that not many other respondents specified the change in context as motivation for their choice of strategy):

Here, the original context of the personal blog - where the privileged personal communication may 'defuse' the effect of the word 'fuck' - is being changed to that of a magazine for general consumption. I'd therefore change the diction, because in the new context I do not see that the use of 'fuck' adds anything to the information conveyed; in fact, it may actually lessen the educative value of the article by being offensive enough to put the reader off reading it at all.

In the category of potentially inappropriate or offensive content, neither the strategy of neutralising adaptation nor the strategy of omission was selected once; instead this category showed a comparatively higher selection of the refusal-to-translate option, with 18 selections out of 62 (or 29\%). ${ }^{12}$ Therefore, it seems as though the respondents chose one of the two polar opposite approaches when it came to content that may be inappropriate for or offensive to a particular target audience.

The strategy distribution patterns for sexism and racism are relatively similar, which suggests that these ethical problems are handled in a similar manner. In both categories, literal translation is strongly favoured, but with some inclination to neutralise or adapt the text, and even refusal to translate in some instances. For example, some of the respondents chose neutralising adaptation for Text 3, the song lyrics, stating that they would tone down the ethnic labelling in this text, while other respondents indicated that they would refuse to translate Text 2, the magazine article about femininity, because they said the generalisations offended them.

The cross-tabulation of ethical motivations cited per problematic content yielded some interesting results (see Figure 4).

\footnotetext{
${ }^{12}$ While there was some concern as to whether the shift in reading context specified in the contextualisation of Text 8 (from implied leisure reading for the source text to the educational context for the target text) would affect the selection of strategies, the distribution of strategies for Texts 8 and 9 is almost identical, which alleviates this concern.
} 


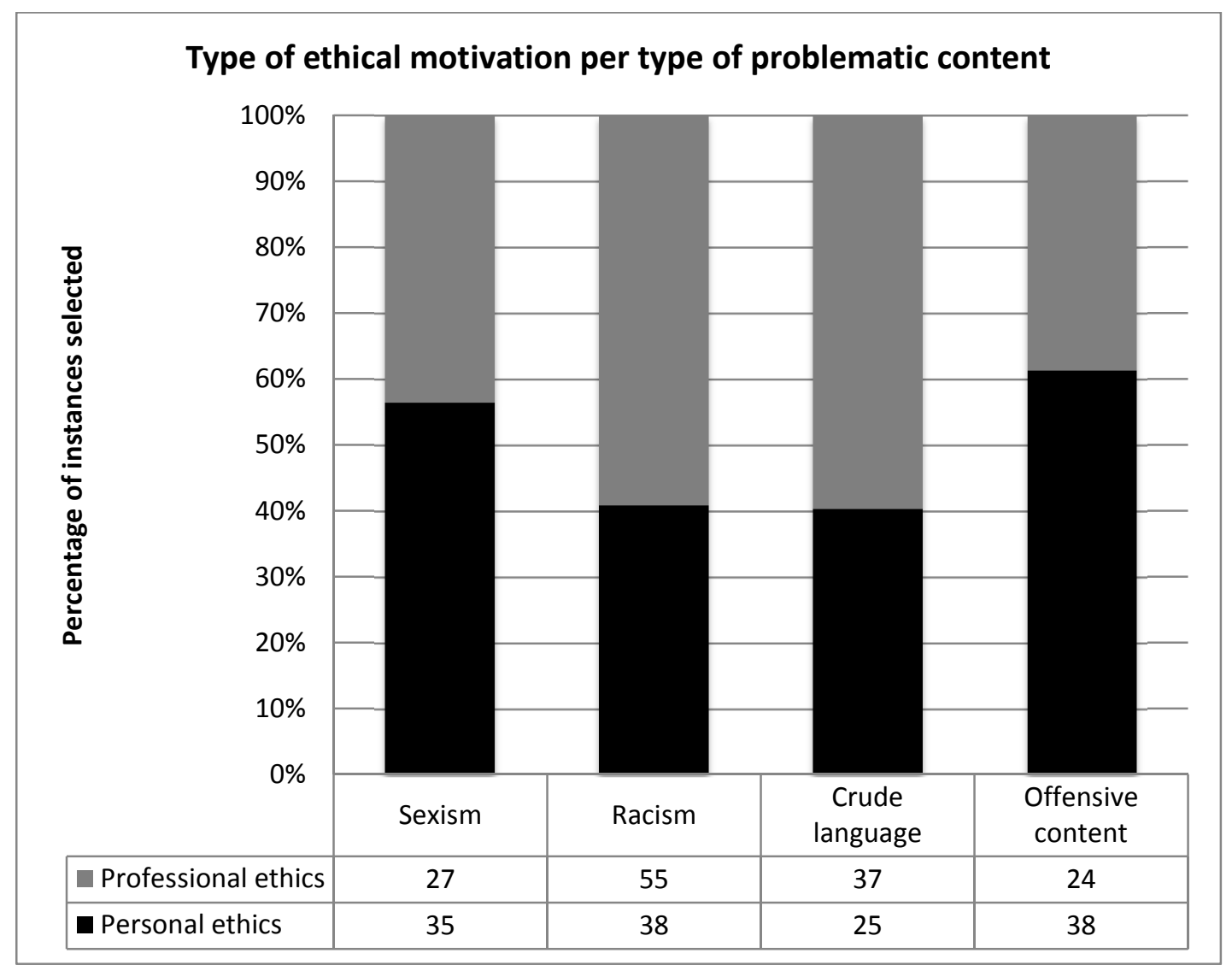

Figure 4. Number and percentage of times personal or professional ethics chosen as motivation per problematic content

While all four categories demonstrate the strong effects of both personal and professional ethics, personal ethics does appear to take precedence in decisions about how to translate texts that are sexist (selected $56 \%$ of the time over $44 \%$ for professional ethics) and texts that contain potentially inappropriate content (selected $61 \%$ of the time over $39 \%$ for professional ethics). The effect of professional ethics is somewhat stronger than that of personal ethics for texts that are racist $(59 \%$ over $41 \%)$ or that contain crude language $(60 \%$ over $40 \%)$.

The respondents may, of course, have cited personal ethics more frequently in the sexism category because there were many more female respondents than male (though it should be noted that some of the male respondents also found the sexist texts, particularly Text 2, particularly problematic, as indicated by their self-formulated motivations). Regardless of the reason, sexism still seems to be a personally contentious issue for the respondents, more so than racism. This may be the consequence of the demographics of the sample and the power relations in which respondents typically find themselves involved: as women, the respondents may well feel themselves at the receiving end of oppressive patriarchal discourses; however, in terms of race, respondents most likely typically do not find themselves the target of racially motivated oppression and exclusion. Another possible reason for the category of racism eliciting more citations of professional ethics for decision-making could be related to the choice of texts. Two of the three texts in this section were literary texts, and the creative nature of these texts (as well as the fact that both are from eras far removed from the present) might have ameliorated the influence of personal ethics. Whatever the reason, clearly ethics is influenced by an individual's experiences as subject within the web of discourses that constitute society. 


\subsubsection{The role of text type}

From the cross-tabulation of translation strategies with text type (see Figure 5), it is evident once more that literal translation is by far the favoured translation strategy across all four text types. The preference for this translation strategy is particularly strong for text types that are overtly linked to a particular author (academic and literary texts), and/or that have an aesthetic function (literature and children's literature), suggesting that awareness of text type and function does have some role to play in the selection of the literal translation strategy.

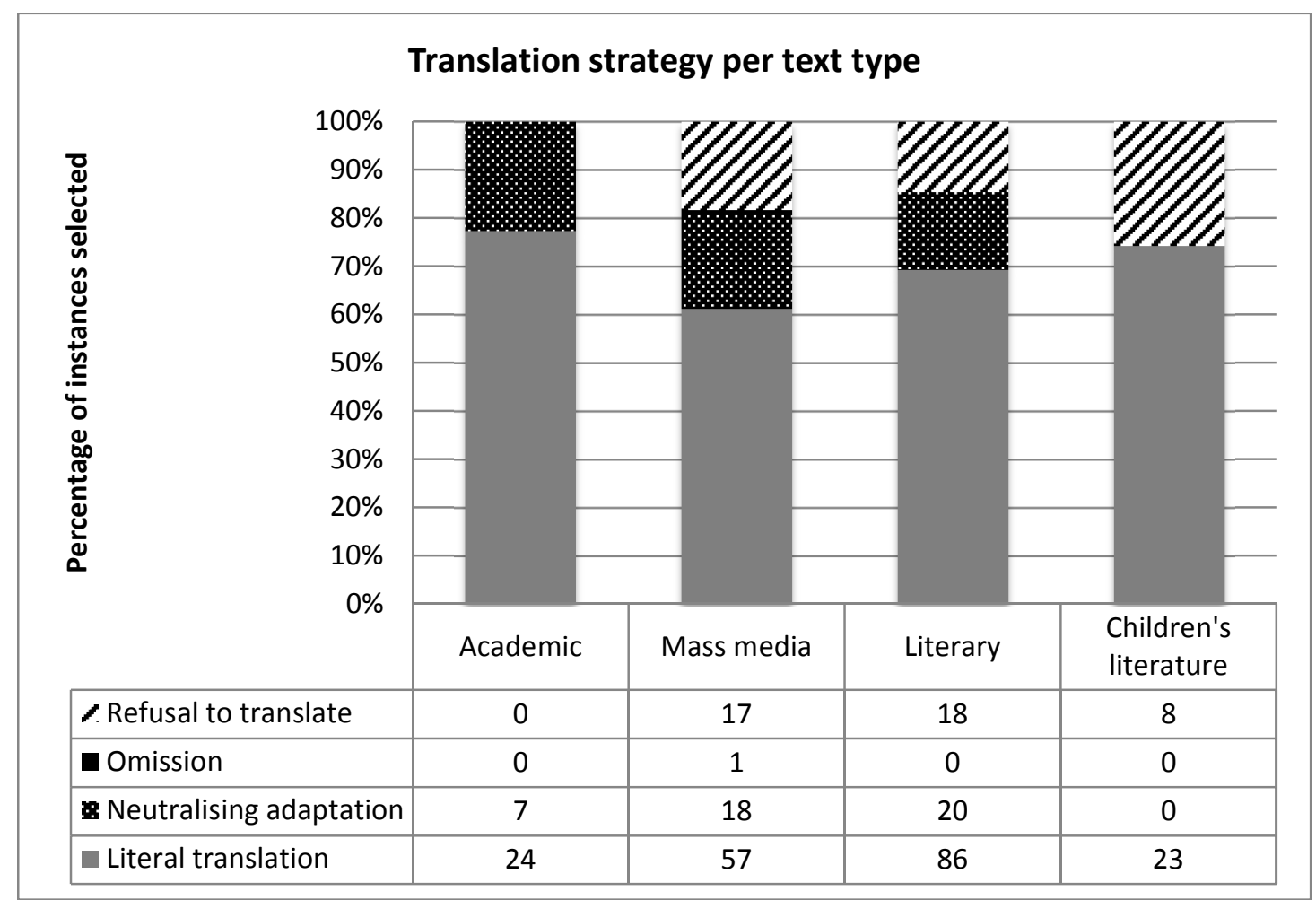

Figure 5. Number and percentage of times translation strategies chosen per text type

In the case of literary texts for children, the respondents chose either refusal to translate (chosen 8 out of 31 instances, or $26 \%$ of the time) or literal translation (chosen 23 out of 31 instances, or $74 \%$ of the time). This text type therefore elicited a strong preference for remaining faithful to the source text (as one would expect for an aesthetic, expressive text). However, because people typically have definite ideas about appropriate material for children, refusal to translate also figures comparatively strongly as a strategy for this text type. This finding does run counter to the general view that adaptation is regarded as a necessary precondition for the translation of children's literature (see, for example, Nikolajeva 1996, Oittinen 2000), but it is likely that the kind of ethical problem involved in this text is of a different type than the kind of translation problems that usually prompt the perceived need to adapt children's books in translation.

The literary and mass-media text types show some similarities, with neutralising adaptation and refusal to translate occurring as strategies selected for both text types, in addition to the dominant literal translation strategy. The single occurrence of omission is in the mass-media category, for Text 7 (the blog text containing swearing). 
In the case of the academic text type, refusal to translate does not figure as a choice at all, with responses spread between literal translation $(77 \%$, or 24 out of 31 times) and neutralising adaptation ( $23 \%$, or 7 out of 31 times). It appears that formal, informational texts are less inclined to prompt a refusal to translate, and children's book texts with potentially inappropriate material are most likely to provoke this response, but least likely to elicit adaptation as a strategy. Of course, it should be kept in mind that the particular ethical problem presented in these text types may have a confounding effect (so that the findings reflect a response to the ethical problem, rather than the text type), especially given that there is just one text in each category. Nevertheless, the findings here may form a starting point for further, more rigorous investigation.

The graph for the category of ethical motivation selected per text type is presented in Figure 6 .

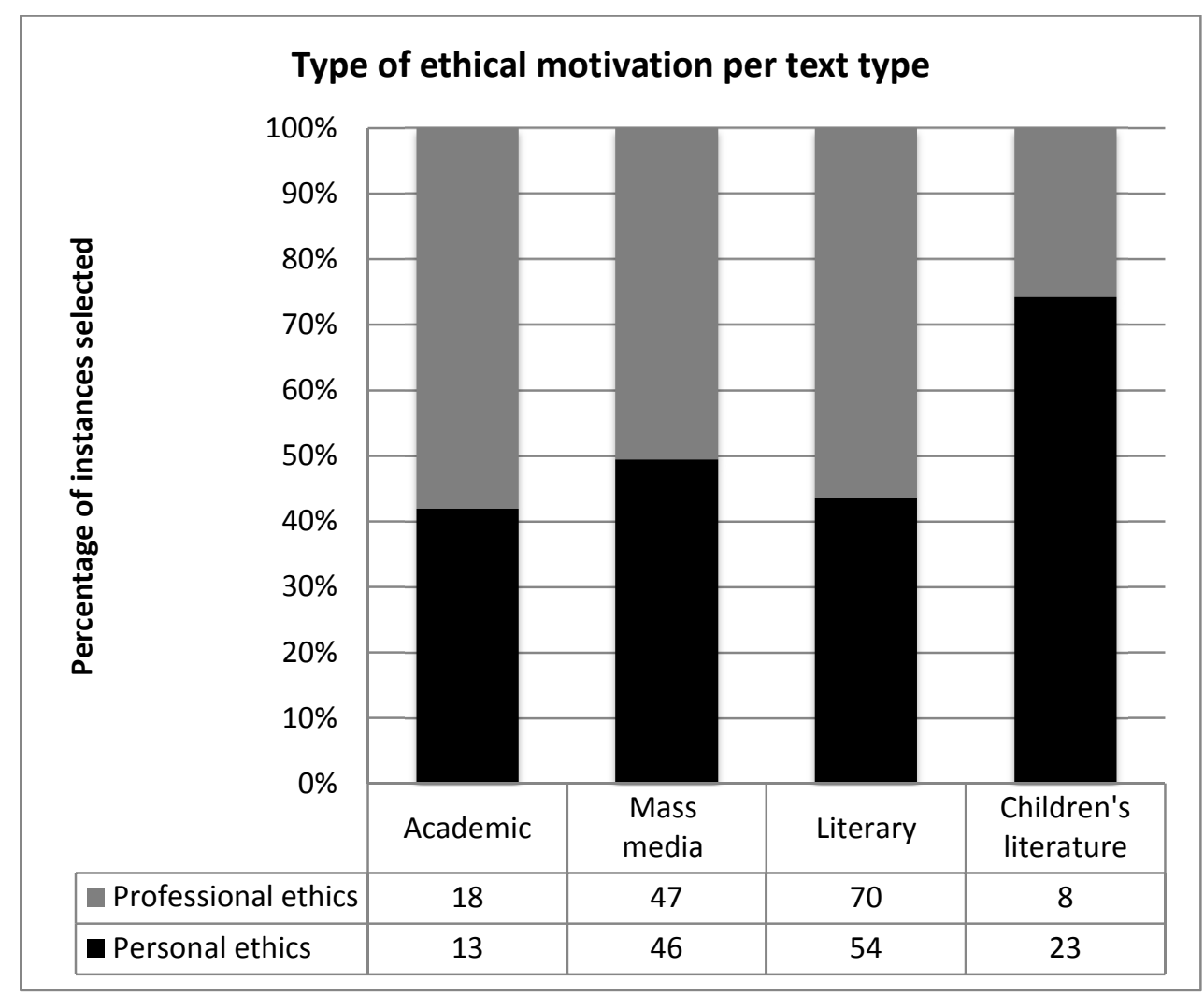

Figure 6. Number and percentage of times personal and professional ethics chosen per text type

In the first instance, it is evident that in the case of academic as well as literary texts, professional ethics plays a slightly more important role in decision-making than personal ethics does. In the case of media texts, professional and personal ethics appear to play an almost equal role. These slight differences aside, for these three text types, personal and professional ethics both exert a strong influence. However, children's literature appears to be the exception, with personal ethics (selected $74 \%$ of the time, or in 23 out of 31 instances) clearly playing a much stronger role than professional ethics (cited $26 \%$ of the time, or 8 out of 31 times). Thus, children's literature appears to elicit a personal, emotional response rather than a rote professional response, most likely because the text type tends to elicit strong opinions about suitability even when translation is not involved (though the confounding effect of the type of problem cannot be discounted). In the case of this text, the pre-formulated personal ethical 
motivations were either positive ("I believe it is important to be open about sexual preferences") or negative ("I do not think this information is appropriate for children"). Two self-formulated motivations for Text 8 suggest other kinds of personal opinions respondents offered as motivations for their choices:

It is important for children to learn about same-sex relationships from some 'official', 'authoritative' source like a school book or teacher, rather than from schoolyardsensationalism.

Whilst I believe in being open and honest with children, I cannot bring myself to translate such a text, because I don't think I would be happy about my child learning this information from a schoolbook.

In considering the role of personal ethics, and its relationship with the selection of translation strategies, it should be kept in mind that personal ethics may be associated with positive as well as negative evaluations of a text, and with literal translation strategies as much as with decisions not to translate a text. In the case of the children's literature text, 15 of the 23 respondents $(65 \%)$ who selected literal translation in fact indicated that they would translate literally because they felt that it was important to be open about sexual preferences (a personal motivation), as opposed to $8(35 \%)$ of the respondents who indicated they would choose the literal translation strategy for professional reasons. Literal translation, as has already been pointed out, should therefore not be equated only with narrower professional ethical motivations, but may also be the consequence of motivations that spring from the translator's personal subjectivity.

\subsubsection{The role of experience and age}

For the analysis of the influence of experience, respondents' levels of experience were combined into three categories, namely "less than ten years' experience", "ten to twenty years' experience", and "more than twenty years' experience".

Firstly, the cross-tabulation of number of years' experience with the selection of translation strategies shows that less experienced respondents are more likely to make changes to and adapt the text (see Figure 7). 


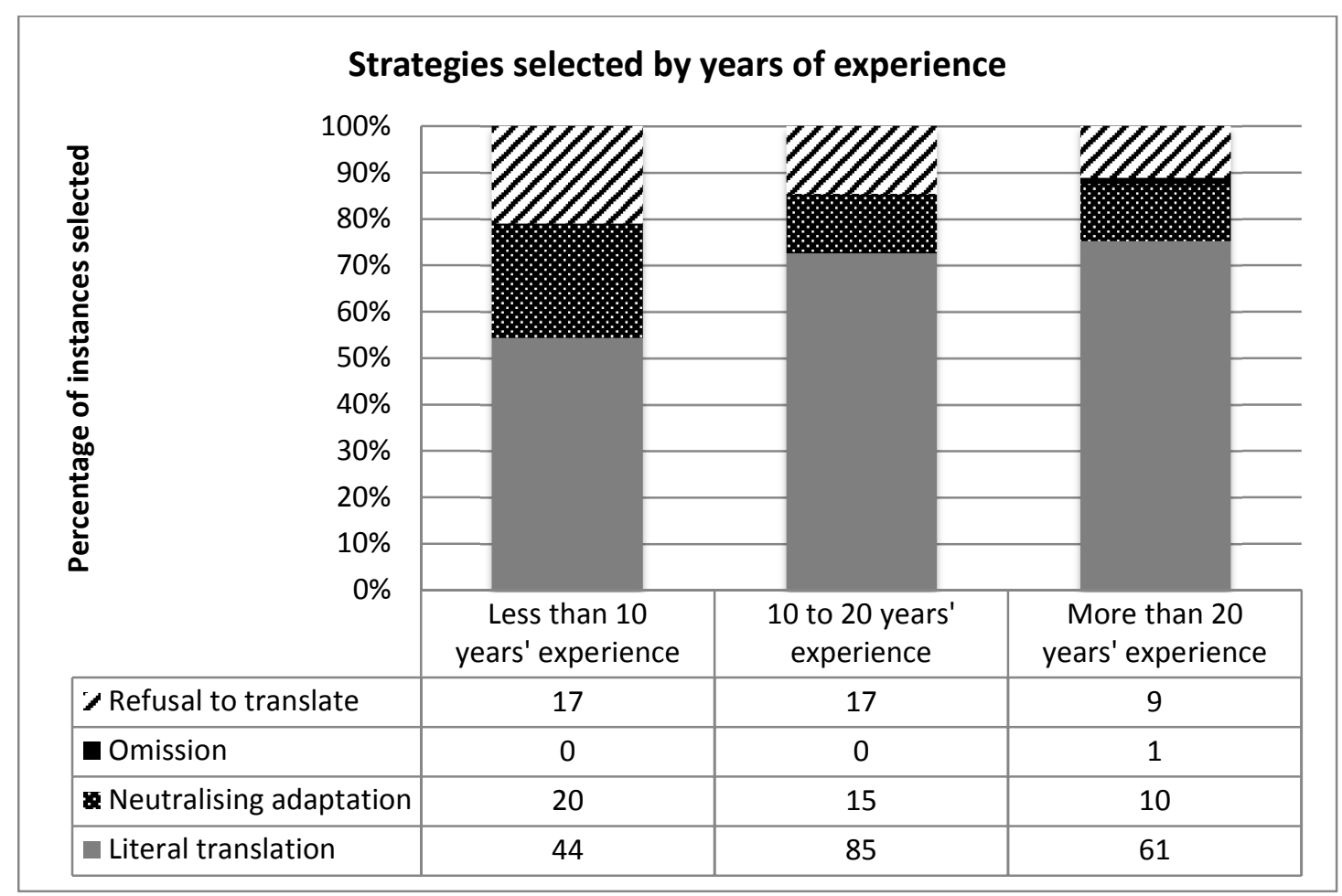

Figure 7. Number and percentage of times translation strategies chosen per respondents' years' experience

This trend becomes very clear when the data for the two groups at the extremes of experience levels are considered. The selection of literal translation strategies is much more frequent among respondents with more than twenty years' experience $(75 \%$ of the time, or 61 out of 81 instances) than among respondents with less than ten years' experience (54\% of the time, or 44 out of 81 instances). On the other hand, the percentage frequency of neutralising adaptation and refusal to translate as strategies is higher for the group of least experienced translators $(25 \%$ and $21 \%$ of the time, respectively) than for the group of most experienced translators $(12 \%$ and $11 \%$ of the time, respectively).

Therefore, in this study the least experienced respondents were more willing to move beyond the idea that accuracy and faithfulness equates with ethical translation. It may be that the more experienced translators have been conditioned to behave in a certain way by professional exposure, whereas less experienced translators are still developing a style and might be less aware of what the conventional views of professional conduct are or what is expected of them in accordance with codes of conduct.

As far as the relationship between number of years' experience and the selection of professional or personal ethics as a motivation for translation strategies is concerned, it was found that the more experienced respondents were more likely to cite professional ethics as a motivation for their selection of translation strategies (see Figure 8). Conversely, the less experienced the respondents were, the more likely they were to cite personal ethics as motivation for their decisions. 


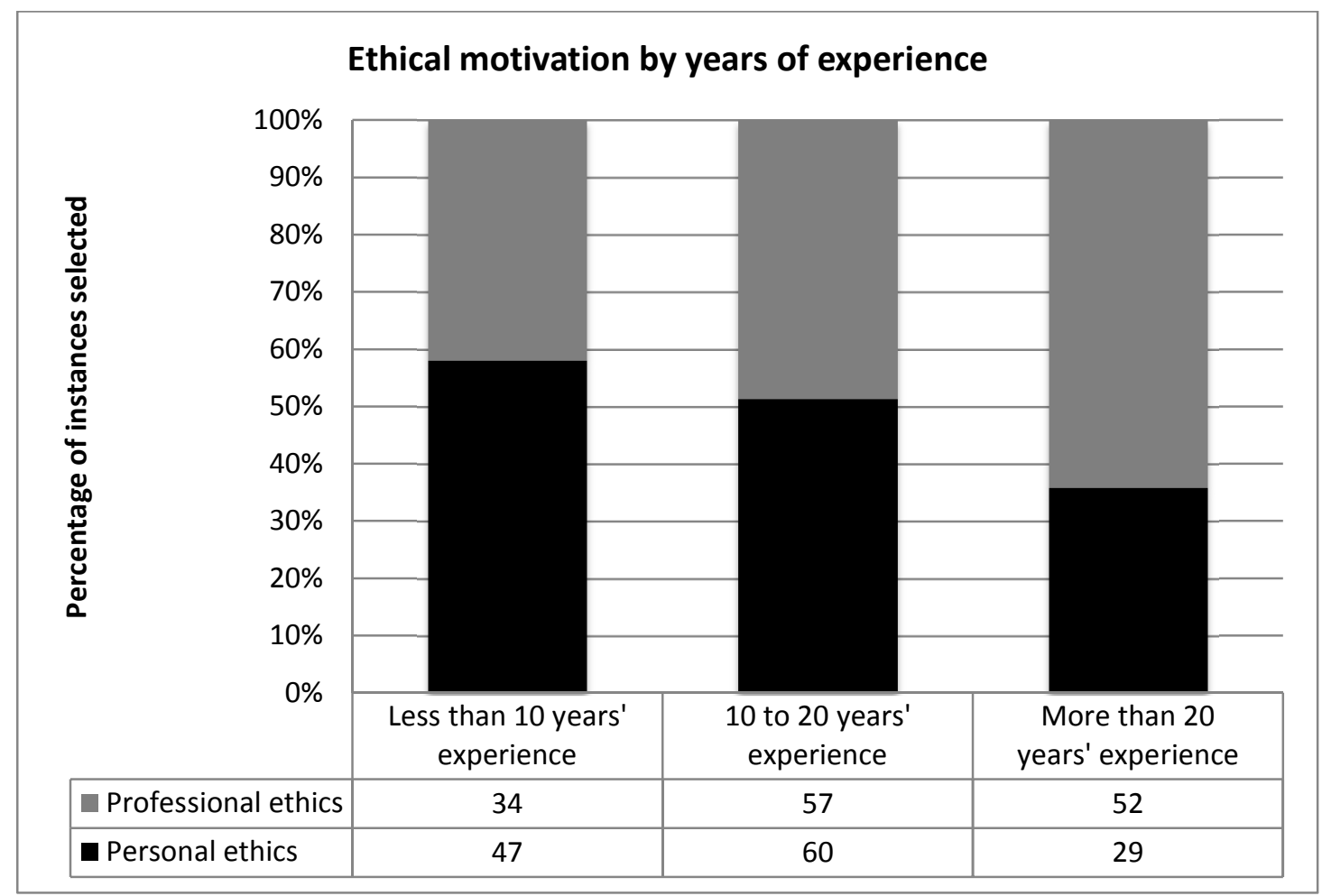

Figure 8. Number and percentage of times personal and professional ethics chosen per respondents' years' experience

The most inexperienced group of respondents demonstrate a smaller margin of difference between personal and professional ethics, but personal ethics is cited more frequently at $58 \%$ of the time ( 47 out of 81 instances) over $42 \%$ of the time (34 out of 81 instances) for professional ethics. Conversely, the most experienced respondents cited professional ethics more frequently, with a larger margin of difference between professional and personal ethics. In this group, professional ethics was cited as motivation $64 \%$ of the time (52 out of 81 instances) and personal ethics only $36 \%$ of the time ( 29 out of 81 instances). This suggests that as translators gain more experience, they are more likely to motivate their choice of translation strategies from an externally circumscribed professional subjectivity, rather than an internally prompted personal subjectivity.

These findings regarding experience raise additional questions about the effect of related variables, such as age and educational background (including translation training). The questionnaire did not include any questions regarding educational background, but did solicit respondents' ages. Generally speaking, as can be seen in Figure 9, there is a clear correspondence between age and increasing experience, though the correspondence is not perfect - with some participants in all age groups other than the oldest having less than 10 years' experience. 


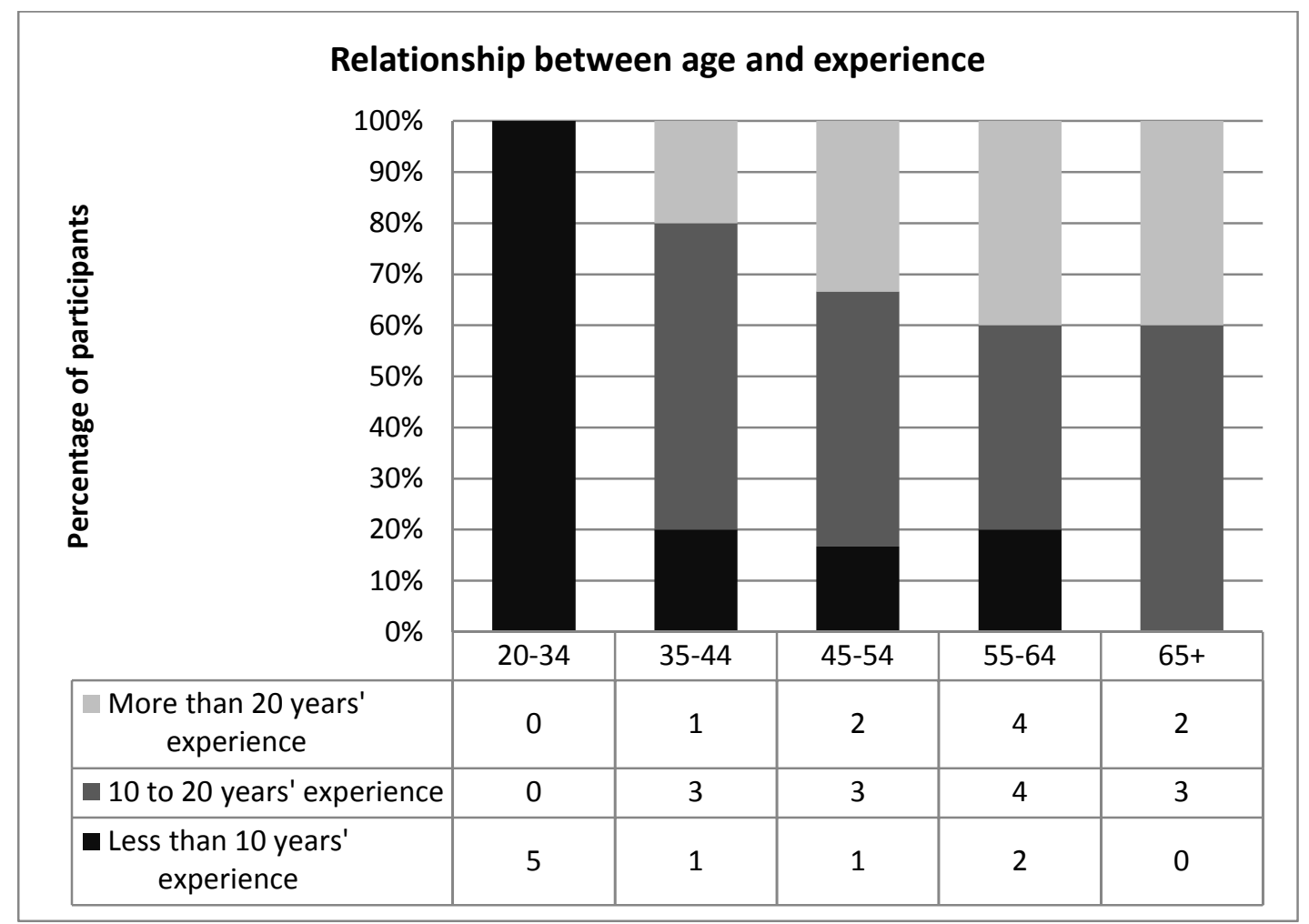

Figure 9. Relationship between age and experience

Against this background, the graphs showing the relationship between age and the selection of translation strategies (Figure 10) and ethical motivation (Figure 11) demonstrate patterns that show a somewhat different effect for age than for experience. Figure 10 shows that the preference for literal translation as a strategy tends to increase from the youngest age group, up until the 45-54 age group, after which it declines again for the two older age groups, returning to much the same level as for the youngest age group. The selection rate of refusal to translate as an option is highest in the youngest and oldest age groups, while the willingness to adapt problematic material tends to be higher in younger age groups. 


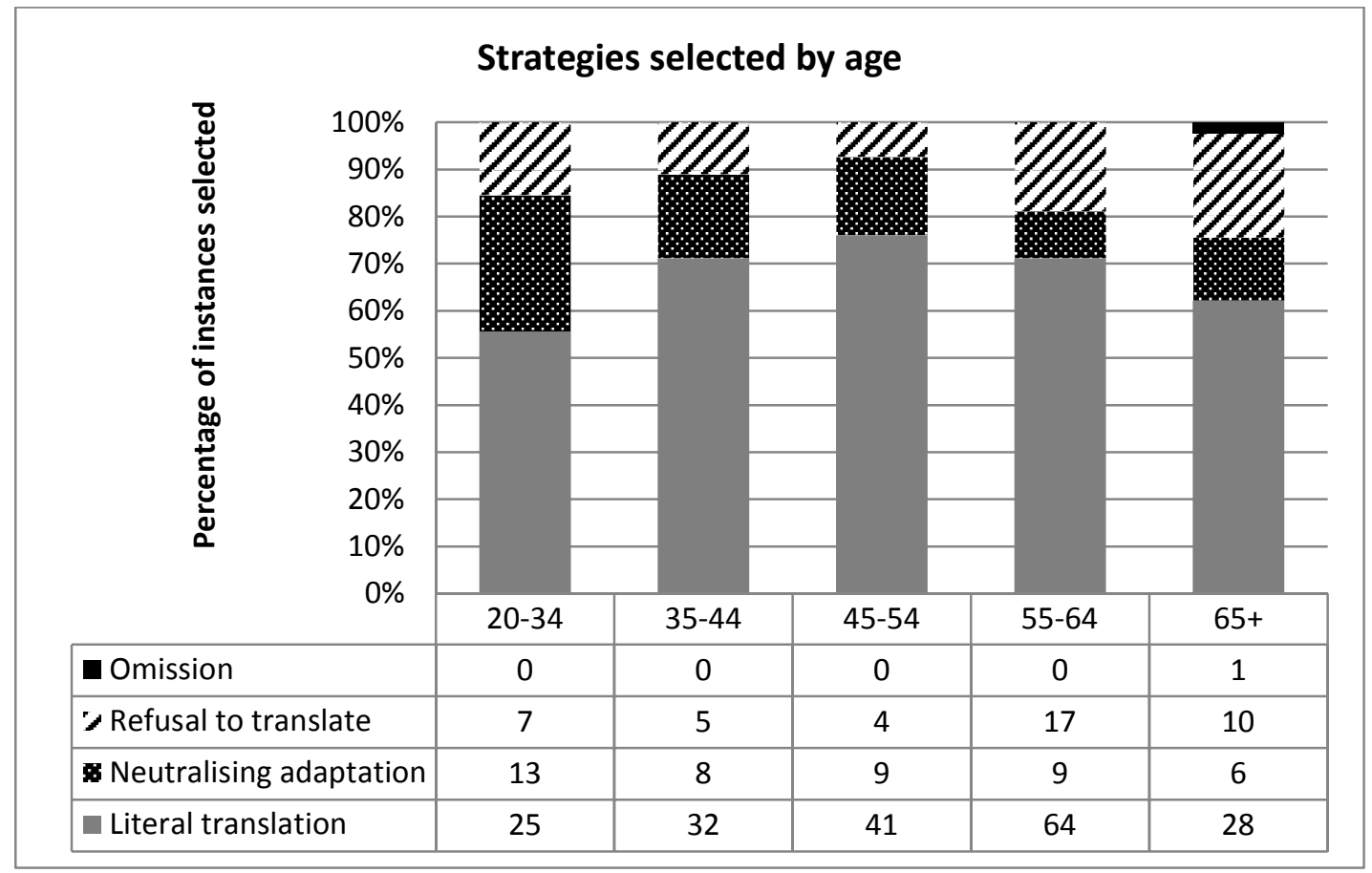

Figure 10. Number and percentage of times translation strategies chosen per respondent age group

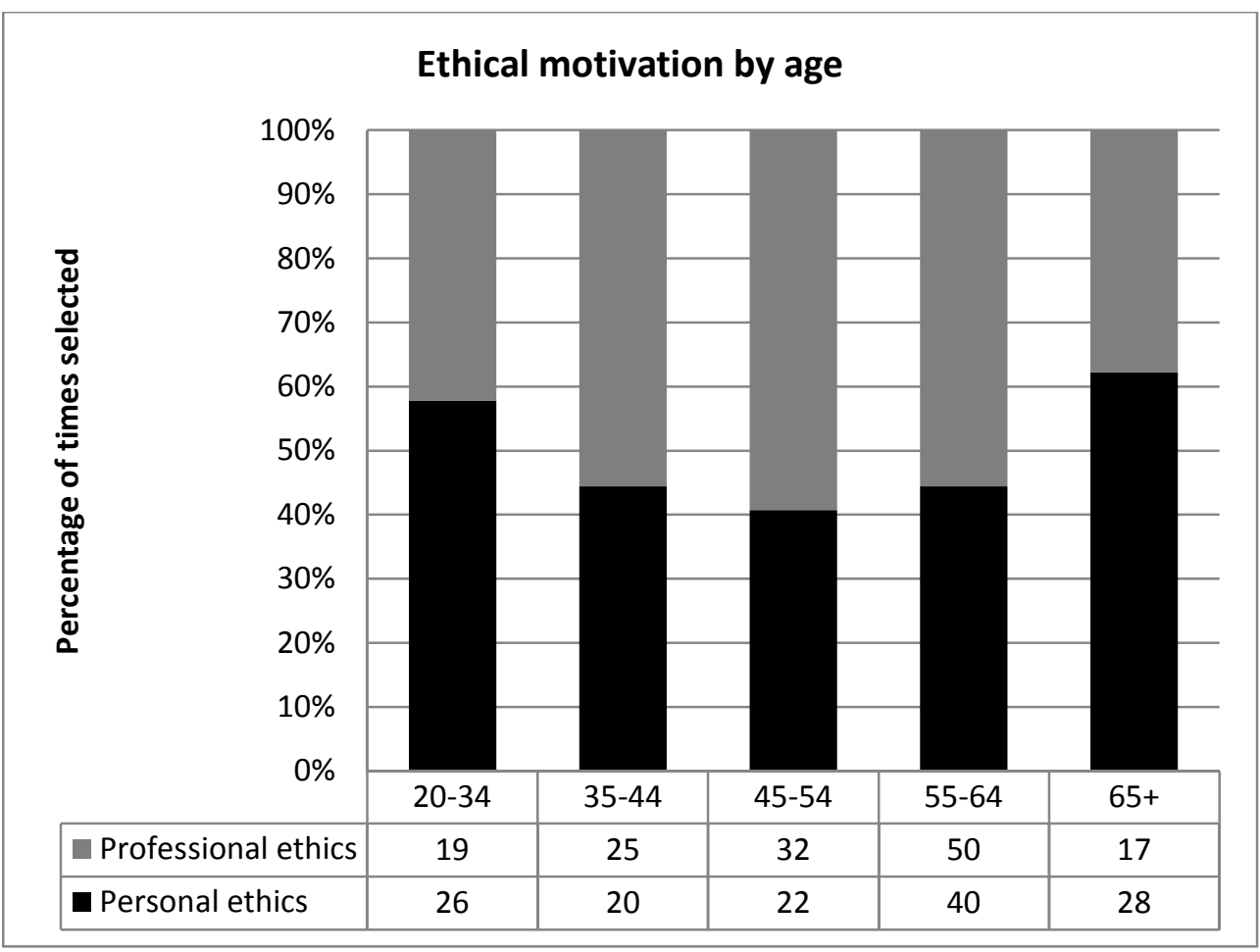

Figure 11. Number and percentage of times personal and professional ethics chosen per respondent age group

Similarly, the role of personal ethics tends to be strongest for the oldest and youngest age groups in the sample, with professional ethics dominating in the middle three age groups. 
Figures 10 and 11 are suggestive of the idea that experience and age may play roles independent of each other, though it is difficult to say whether the effect is really one of age or generation. The investigation of these findings would require a research design more specifically geared towards separating the effects of these variables, and others, such as educational background.

\section{Conclusions}

In summary, it is clear that translation strategies premised on faithful translation are by far the preferred choice of the translators in this sample when faced with ethically challenging material. These translators appear to subscribe to the principle of ethical translation as faithful translation, and are loathe to effect radical changes to a text in translation - particularly evident in the fact that omission is virtually never chosen as a translation strategy. This general tendency may be regarded as the consequence of translators' risk aversion - in this case, risk aversion involves the prudent course of action of deferring to the authority of the source text and author, so that the responsibility for saying something can remain vested in somebody else, somebody with authorial clout (see Pym 2008:324-325). The type of ethical problem, text type, translator age, and translation experience all appear to exert some influence on the choice of strategy, although this influence never overrules the overall preference for faithful translation. As far as the type of ethical problem is concerned, crude language appears to be one category where there is a comparatively greater willingness to adapt the text, while in the category of potentially inappropriate content, there is a comparatively greater likelihood of translators' refusing to undertake the translation. It appears that there is some distinction between surface and intrinsic elements of a text, with translators viewing surface elements (such as crude language) as more open to adaptation; however, as has been pointed out in section 2.4.2, this finding should be read against the limitations of the research design, and requires further, more rigorous investigation.

In the case of text type, it appears that formal, informational texts are less likely to prompt a refusal to translate, and children's literature containing potentially inappropriate material is most likely to provoke this response, but least likely to elicit adaptation as a strategy. This is an unusual finding, given the general view that children's literature is particularly amenable to manipulation in translation, and should be interpreted with caution against the background of the limitations of the research design (but see also comments on this issue in the following paragraph). Overall, for all text types, literal translation dominates, but especially for texts that are strongly tied to a "visible" author, suggesting translators' acceptance of a secondary or deferential role as text producers. One respondent in this study formulated this role very clearly in the following comment: "We do not have a right as translators to adjust/omit words according to our beliefs or ethics concerning the use of words. The writer's original is to be translated in such a way that it conveys that which the writer was trying to achieve". Lastly, experience appears to play an important role in the selection of translation strategies, with greater experience corresponding to a greater preference for faithful translation. The effects of experience and age appear not to correlate directly, so that age appears to have its own, independent, effects, with the youngest and the oldest respondents in the sample least likely to select literal translation as an option, and most likely to refuse a translation commission.

In terms of ethical motivation, both personal and professional ethics exert a strong influence, reiterating the point made by various scholars that it may be difficult to separate personal and professional ethics in translation. The findings of this study suggest that the selection of literal 
or faithful translation strategies is generally motivated by professional ethics, with the strategy of refusal to translate mostly the consequence of personal ethics. However, this should not be regarded as an absolute correlation. For example, in a considerable number of instances, respondents did select personal motivations for their choice of a literal translation strategy, usually founded on some kind of personal positive valuation of the text, as was the case for the children's literature text in the study.

The almost equal pull of personal and professional ethics is visible across type of ethical problem and text type. For the participants in this study, personal ethics does appear to have a stronger effect for ethical problems related to sexism and potentially offensive content, with professional ethics featuring more strongly for racism and crude language. It is very likely that these differences have to do with the demographics of the sample, and this finding suggests the importance of subject position and individual background in ethical motivation. (In this respect, it is crucially important that the findings of the current study be extended and refined by repeating the survey with African-language translators, and in contexts other than that of South Africa.) In the case of text type, professional ethics plays a slightly more important role for literary and academic texts, while children's literature makes a much stronger appeal on personal ethics.

Lastly, it appears that the greater adherence to faithful translation that correlates with experience is accompanied by a greater recourse to professional ethics in motivations for translation decisions. It therefore seems as if greater experience corresponds to a greater likelihood of the narrower professional, codified view of ethics being used as a frame of reference for translation decisions. Again, age appears to have an effect independent of experience: the youngest and oldest respondents in the sample were more likely to motivate their translation decisions from the position of personal rather than professional subjectivity.

This study is a first attempt to approach ethical decision-making in translation in a quantitative and empirical way. However, it is clearly limited in a number of ways, and, as such, its findings should be regarded as explanatory hypotheses which need to be tested in more rigorous ways in different contexts. In particular, in further work along these lines, it will be important to employ research designs that allow for a more precise, statistical teasing apart of the effect of the different variables that play a role in the selection of translation strategies, and the relative roles of personal and professional ethics in this process.

Ultimately, research such as this contributes to the ongoing conversation on ethics in translation, by providing actual empirical data on translators' behaviour and motivations (albeit in reported rather than directly observed form). In particular, the current study raises the question of whether, as scholars like Baker (2011) and Tymoczko (2007) have argued, the "neutrality" and "pragmatism" which are the hallmarks of this professionalism may "deaden [translators'] ethical sensibilities, thus discouraging their agency and disempowering them in multiple ways" (Tymoczko 2007:319). A pertinent point suggested by this research, then, is whether professional codes of ethics ought to encourage, to a greater degree than they currently do, the role of personal ethics, and particularly the wider socio-cultural responsibility of the translator. While some scholars (like Chesterman 2001) are likely to disagree with this, others, like Tymoczko (2007), make a compelling case in favour of this approach to translator ethics, suggesting the importance of continued conversation on this matter. 


\section{References}

ATA (American Translators Association). 2010. American Translators Association code of ethics and professional practice. Available online: http://www.atanet.org/aboutus/ code_of_professional_conduct.php_(Accessed 13 March 2013).

AUSIT (Australian Institute of Interpreters and Translators). 2012. AUSIT code of ethics and code of conduct. Available online: http://ausit.org/AUSIT/Documents/Code_Of Ethics Full.pdf(Accessed 13 March 2013).

Baker, M. 2006. Translation and conflict: A narrative account. London: Routledge.

Baker, M. 2011. In other words: A coursebook on translation. London: Routledge.

Bassnett, S. and H. Trivedi (eds.) 1999. Post-colonial translation: Theory and practice. London: Routledge.

Chesterman, A. 1997. Memes of translation. Amsterdam: John Benjamins.

Chesterman, A. 2001. Proposal for a Hieronymic oath. In A. Pym (ed.) The translator: Studies in intercultural communication. Special issue: The return to ethics 7(2): 139-154.

Cronin, M. 1996. Translating Ireland: Translation, languages, cultures. Cork: Cork University Press.

Cronin, M. 2003. Translation and globalization. London: Routledge.

FIT (International Federation of Translators). 1994. Translator's charter. Available online: http://fit-ift.org.dedi303.nur4.host-h.net/index.php?frontend action=display_compound text content\&item_id=3367 (Accessed 13 March 2013).

Gouanvic, J.-M. 2001. Ethos, ethics and translation: Toward a community of destinies. In A. Pym (ed.) The translator: Studies in intercultural communication. Special issue: The return to ethics 7(2): 203-212.

Hermans, T. 2009. Translation, ethics, politics. In J. Munday (ed.) The Routledge companion to translation studies. London: Routledge. pp. 93-105.

Hinman, L.M. 2013. Ethics: A pluralistic approach to moral theory. Andover: Wadsworth Cengage Learning.

Hooker, B. 2010. Consequentialism. In J. Skorpuski (ed.) The Routledge companion to ethics. London: Routledge. pp. 444-455.

Inghilleri, M. 2009. Ethics. In M. Baker and G. Saldanha (eds.) The Routledge encyclopaedia of translation studies. London: Routledge. pp. 100-104. 
Inghilleri, M. and S.-A. Harding (eds.) 2010. Translation and violent conflict. Special issue of The Translator 16(20). Manchester: St Jerome.

Koskinen, K. 2000. Beyond ambivalence: Postmodernity and the ethics of translation. Tampere: University of Tampere.

Kruger, H. and A. Bevan-Dye. 2010. Guidelines for the editing of dissertations and theses: A survey of editors' perceptions. Southern African Linguistics and Applied Language Studies 28(2): 167-183.

Law, M.A. and H. Kruger. 2008. Towards the professionalisation of editing in South Africa. Southern African Linguistics and Applied Language Studies 26(4): 479-493.

Nikolajeva, M. 1996. Children's literature comes of age: Toward a new aesthetic. New York: Garland.

Niranjana, T. 1992. Siting translation: History, post-structuralism, and the colonial context. Berkeley: University of California Press.

Oittinen, R. 2000. Translating for children. New York: Garland.

Pérez Quintero, M.J. and C. Toledano Buendía. 2001. The transference of discourse values in translation via lexis: Obscene language as a case in point. Revista Alicantina de Estudios Ingleses 14: 177-196.

Pym, A. 2000. On cooperation. In M. Olohan (ed.) Intercultural faultlines: Research models in translation studies I: Textual and cognitive aspects. Manchester: St Jerome. pp. 181-192.

Pym, A. 2008. On Toury's laws of how translators translate. In A. Pym, M. Shlesinger and D. Simeoni (eds.) Beyond descriptive translation studies: Investigations in homage to Gideon Toury. Amsterdam: John Benjamins. pp. 311-328.

Pym, A. 2012. On translator ethics: Principles for mediation between cultures. Amsterdam: John Benjamins.

Santaemilia, J. (ed.) 2005. Gender, sex and translation: The manipulation of identities. Manchester: St Jerome.

SATI (South African Translators' Institute). 2013. Code of ethics for individual members. Available online: http://www.translators.org.za/sati_cms/downloads/dynamic/sati_ethics individual_english.pdf (Accessed 13 February 2013).

Simon, S. 1996. Gender in translation: Cultural identity and the politics of transmission. London: Routledge.

Singer, P. 2011. Practical ethics. New York: Cambridge University Press.

Skorupski, J. (ed.) 2010. The Routledge companion to ethics. London: Routledge. 
Slote, M. 2010. Virtue ethics. In J. Skorupski (ed.) The Routledge companion to ethics. London: Routledge. pp. 478-489.

Spivak, G.C. 1992/2012. The politics of translation. In L. Venuti (ed.) The translation studies reader. London: Routledge. pp. 312-330.

StatSoft Inc. 2011. Statistica (data analysis software system), version 10.

Taivalkoski-Shilov, K. 2008. Subtitling "8 Mile" in three languages: Translation problems and translator licence. Target: International Journal of Translation Studies 20(2): 249-274.

Tymoczko, M. 1999. Translation in a postcolonial context: Early Irish literature in English translation. Manchester: St Jerome.

Tymoczcko, M. 2007. Enlarging translation, empowering translators. Manchester: St Jerome.

Venuti, L. 1998. The scandals of translation: Towards an ethics of difference. London: Routledge.

Venuti, L. 2008. The translator's invisibility: A history of translation. London: Routledge.

Von Flotow, L. 1997. Translation and gender: Translating in the 'era of feminism'. Ottawa: University of Ottawa Press.

Von Flotow, L. 2011. Translating women. Ottawa: University of Ottawa Press.

Watson, G.W., B.T. Teague and S.D. Papamarcos. 2007. Moral hypocrisy: A matter of measures? In A.E. Wurtzel (ed.) Trends in contemporary ethical issues. New York: Nova. pp. $1-14$. 